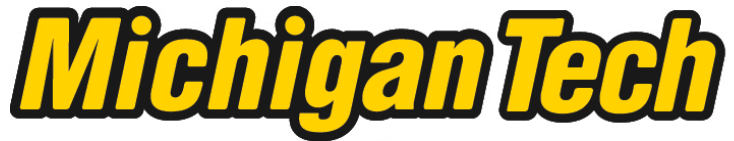 \\ Michigan Technological University Create the Future Digital Commons @ Michigan Tech
}

\section{Assessment of soil erosion vulnerability in rural communities in the vicinity of Motozintla de Mendoza, Chiapas, Mexico : a physical and sociological approach}

Selene B. González-Morales

Michigan Technological University

Follow this and additional works at: https://digitalcommons.mtu.edu/etds

Part of the Civil and Environmental Engineering Commons

Copyright 2012 Selene B. González-Morales

Recommended Citation

González-Morales, Selene B., "Assessment of soil erosion vulnerability in rural communities in the vicinity of Motozintla de Mendoza, Chiapas, Mexico : a physical and sociological approach", Master's report, Michigan Technological University, 2012.

https://doi.org/10.37099/mtu.dc.etds/499

Follow this and additional works at: https://digitalcommons.mtu.edu/etds

3 Part of the Civil and Environmental Engineering Commons 


\title{
ASSESSMENT OF SOIL EROSION VULNERABILITY IN RURAL COMMUNITIES IN THE VICINITY OF MOTOZINTLA DE MENDOZA, CHIAPAS, MEXICO: A PHYSICAL AND SOCIOLOGICAL APPROACH.
}

By

Selene B. González-Morales

\begin{abstract}
A REPORT
Submitted in partial fulfillment of the requirements for the degree of MASTER OF SCIENCE IN ENVIRONMENTAL ENGINEERING
\end{abstract}

MICHIGAN TECHNOLOGICAL UNIVERSITY

2012

(C) 2012 Selene B. González-Morales 
This report, "Assessment of Soil Erosion Vulnerability in Rural Communities in the vicinity of Motozintla de Mendoza, Chiapas, Mexico: A physical and sociological approach", is hereby approved in partial fulfillment of the requirements for the Degree of MASTER OF SCIENCE IN ENVIRONMENTAL ENGINEERING.

Department of Civil and Environmental Engineering

Signatures:

\author{
Report Advisor \\ Department Chair
}

Alex S. Mayer

David W. Hand

Date 


\section{Acknowledgments}

First I would like to thank my advisor Dr. Alex Mayer for his support, dedication, advices during my academic years. There is no way to express my thanks to him since my arrival in this country, thanks for all your patience with me, you always will have a place in my life. I also would like to thank greatly to Dr. Neptali Marcial Ramirez, for being my advisor in Mexico for his support, advices, patience and for his confidence in me. To the members of my committee: Dr. Hugh Gorman for being part of my committee, for all his advices and thoughts shared with me, he taught me to know more about social sciences and that will help me in my professional life. I also want to thank to Dr. Stanley Vitton for being part of my committee.

I greatly want to thank by supporting my graduate education and the source from whom this report was made possible by the generous support of the American people through the United States Agency for International Development (USAID) and the Higher Education for Development (HED) office. The contents are the responsibility of the author and do not necessarily reflect the views of HED, USAID or the United States Government. This support was made through the project "Enhancing the capacity for sustainable forest management and ecosystem service provision in Chiapas and Oaxaca", and I aknowledge the partial support of the Fondo Institucional de Fomento Regional para el Desarrollo Científico, Tecnológico y de Innovación (FORDECYT) of National Council of Science and Technology through the convention 143303 "Gestión $y$ estrategias de manejo sustentable para el desarrollo regional en la cuenca hidrográfica transfronteriza Grijalva" through El Colegio de la Frontera Sur (ECOSUR).

González-Morales 2 
I would like to thank the people from Benito Juarez Centro, Carrizal Centro, Barrio Vicente Guerrero, Barrio Plan Grade, Barrio La Union and Poblado Cambil for their willingness to participate in sharing experiences and thoughts during the fieldwork, as also authorities from Motozintla and Mazapa de Madero municipalities.

I'm greatly thankful for the support of Dr. Karim Musalem, Anahi Hernandez, Erika Gomez, Henry Castañeda, Miguel Martinez, Alfonso Luna, Abel J. Roblero, Coralie Valdebouze, Zeni Hernandez, Sol Gomez, Carlos Velazquez, Jose Ivan Gonzalez and Auden Escalante during the beauty experience of my fieldwork, for their hard work, smiles and happiness that made the work easier.

I also want to mention and thank to my friends in U.S, who helped me to make the life easier in this country: Violeta Cruz, Rocio Jimenez, Mayra Sanchez, Agustin, Lilia and Leila, Alessia Uboni, Julio Rivera, Alicia Sherin, Miriam Rios (for her teachings), Olu Winjobi, Ezequiel Medici, as they also left important memories in my life.

To my family in Houghton, Huguito Gorman and his wife Bonita Gorman for all their support and hospitality, to Alex Mayer and his wife Suzanne thank you very much for all their knowledge shared with me for their appreciation and support during this important stage of my life.

Finally, I want to say THANKS Father And Mother I Love You (FAMILY). Dear Daddy you are always my example, my inspiration, my reason to continue being a strong girl your little girl, thank you so much for your love, your kisses every day showing me how much you love me, I love you so much too. To you Mom (R.I.P) I love you so much Chaparrita hermosa, thank you for your company in most part of my life, I know from the heaven you are looking at me and all these efforts were 
made because of you, thanks to you I gained another stage in my life you are and will be my model to follow forever. To my brothers, Bilmer and his wife and kids, to Mijail, Adin and his wife and kids, to Anival his wife and kid and to Jose Ivan I love you so much, thank you for giving all your love and confidence, I did it again. All of you are my inspiration, always together against the obstacles you are always with me. To you Chaparrito thanks for your love, your advices and smiles, I love you. God bless all of you. Greatly thanked to God for allowing me to be strong despite the difficulties and for giving me the opportunity for getting my MASTER DEGREE. 


\section{TABLE OF CONTENTS}

Acknowledgments

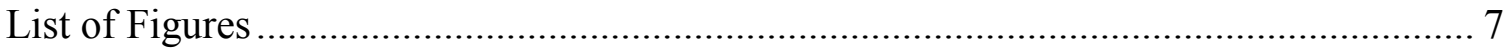

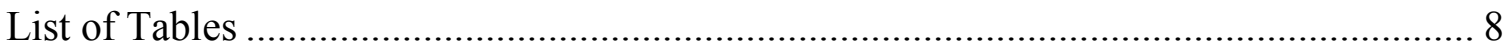

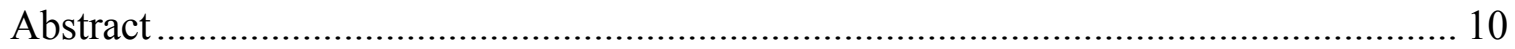

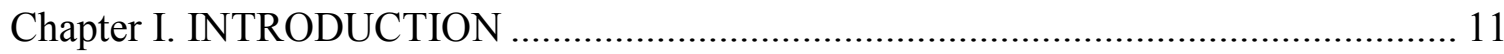

1.1 Definition and importance of soil erosion........................................................... 11

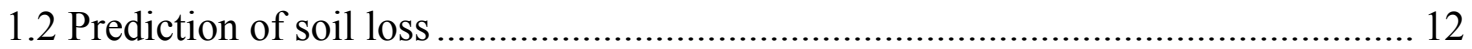

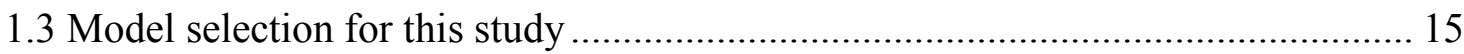

1.4 Knowledge, Attitudes and Practices as perceptions of soil erosion ...................... 16

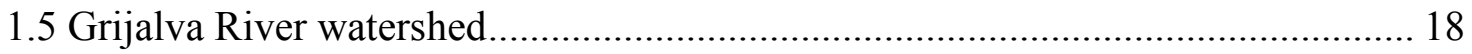

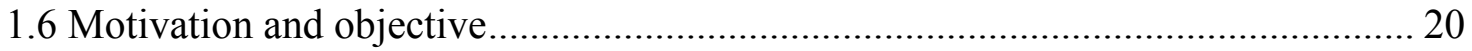

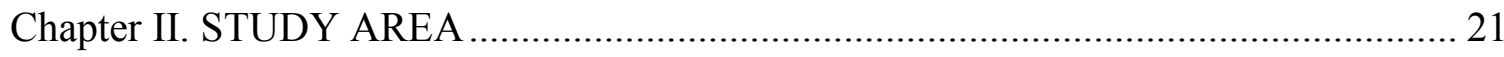

Chapter III. Part 1. METHODOLOGY: RUSLE MODEL ........................................... 25

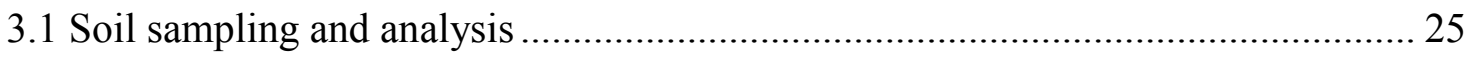

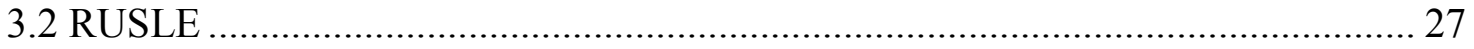

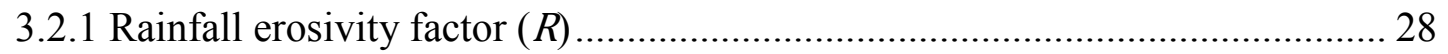

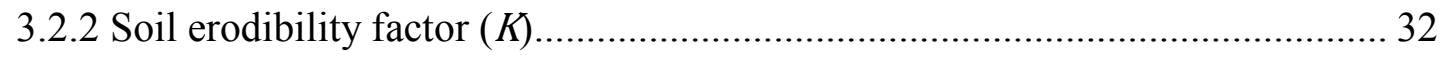

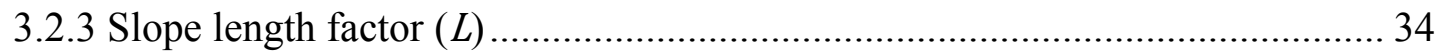




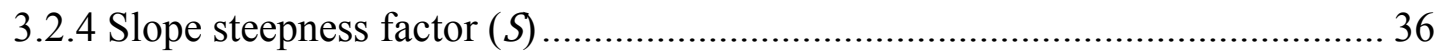

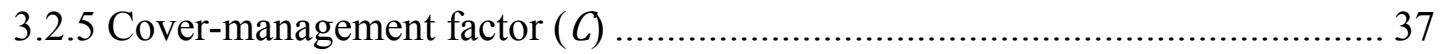

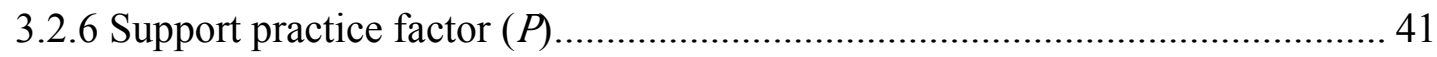

Chapter IV. Part 2.-METHODOLOGY: SURVEY OF COMMUNITY MEMBERS .... 42

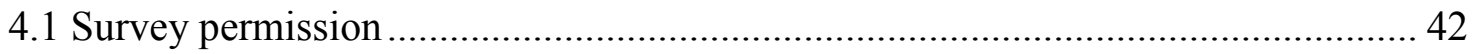

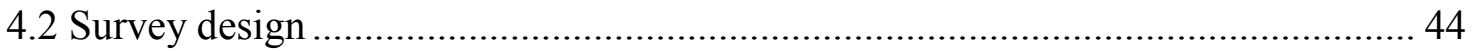

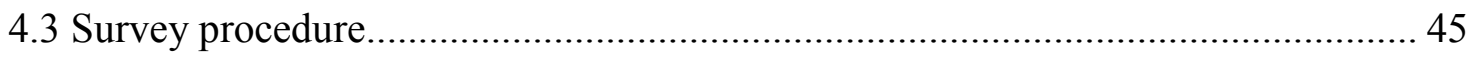

Chapter V. RESULTS AND DISCUSSION FOR SOIL EROSION RATES ................... 47

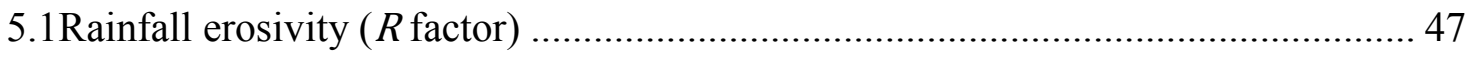

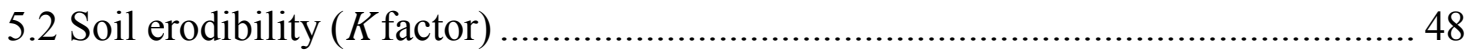

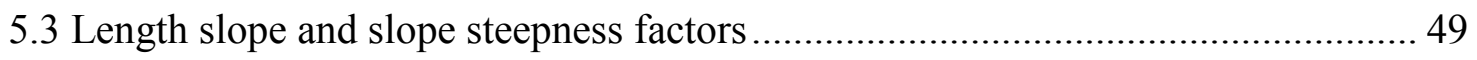

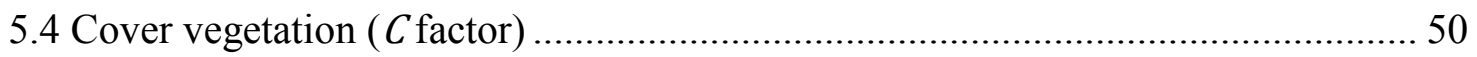

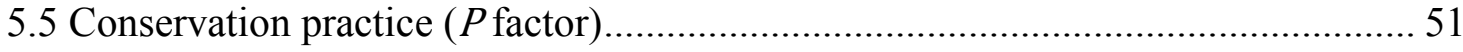

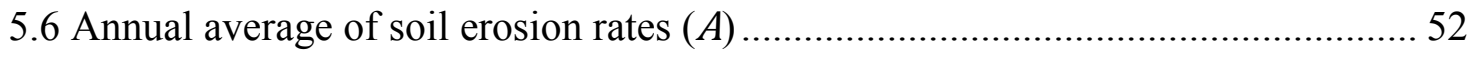

5.7 Limitations of soil erosion rate calculations ....................................................... 54

Chapter VI. RESULTS AND DISCUSSION FOR SOCIAL SURVEYS......................... 56

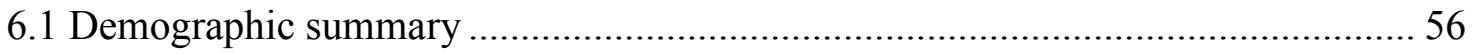

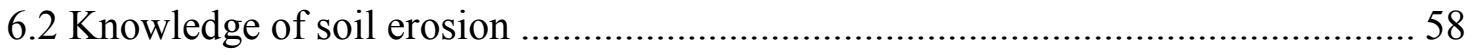

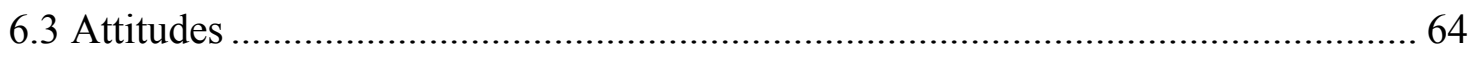




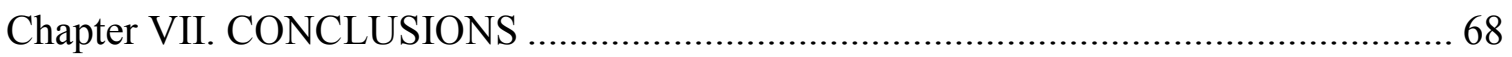

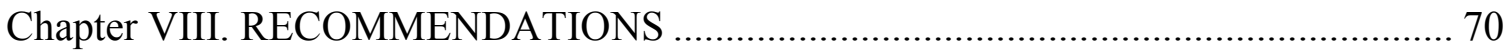

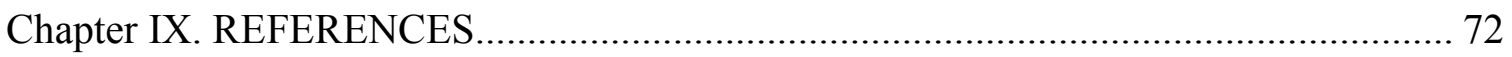

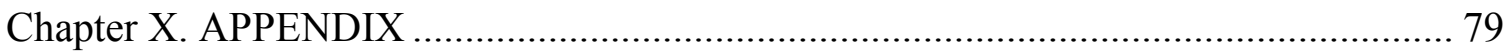

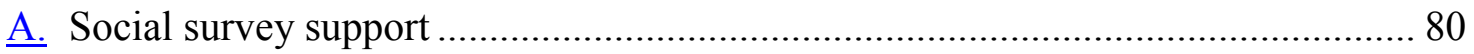

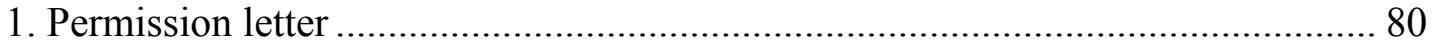

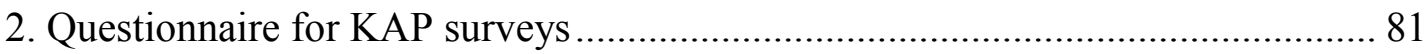

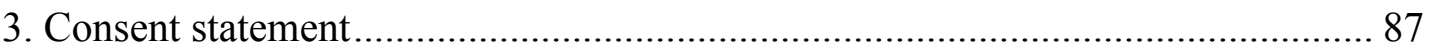

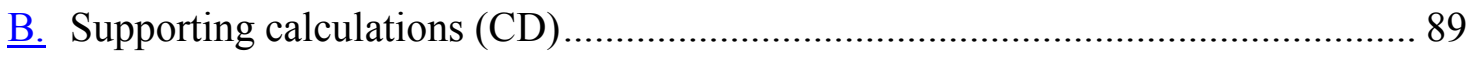

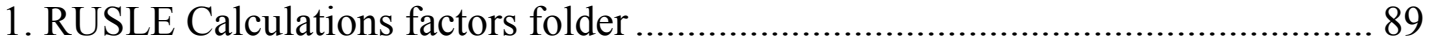

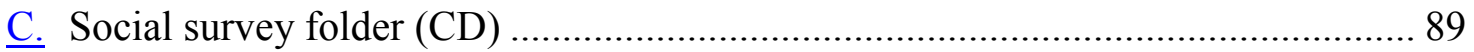

1. Survey general questions and responses per community ............................... 89

\section{List of Figures}

Figure 1: Study area -Motozintla de Mendoza municipality ....................................... 22

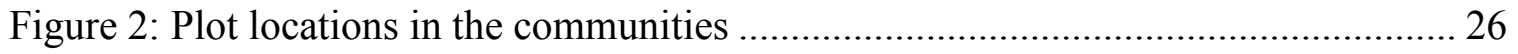

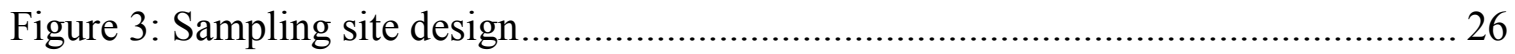

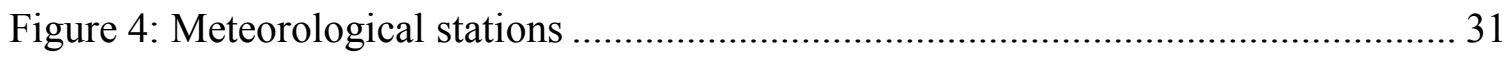

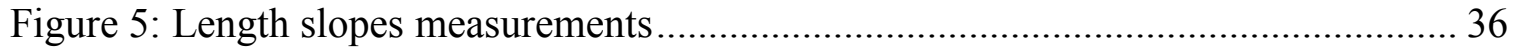


Figure 6: Average monthly precipitation of Buenos Aires Station (1980-2009).....

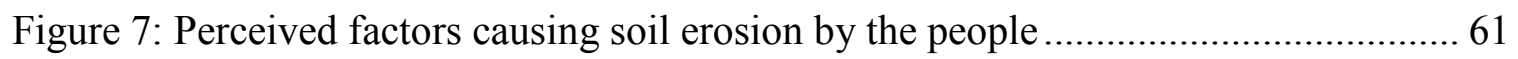

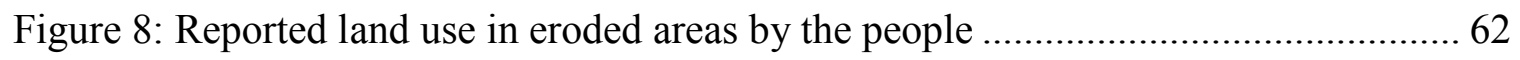

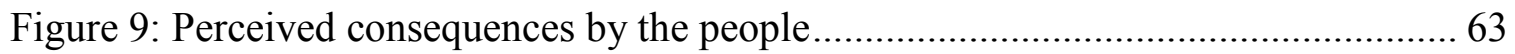

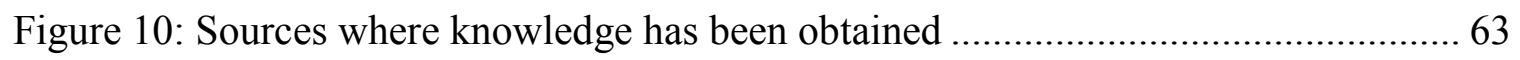

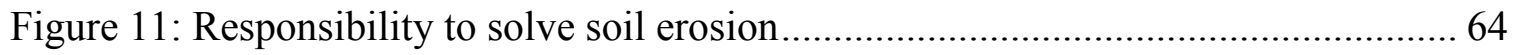

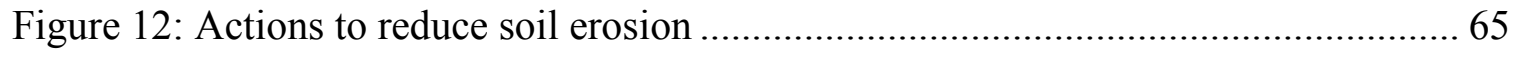

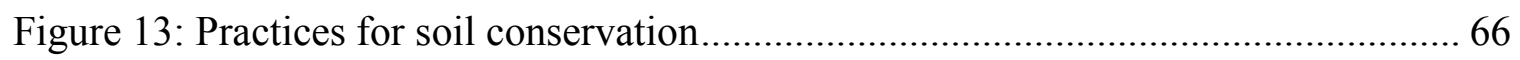

\section{List of Tables}

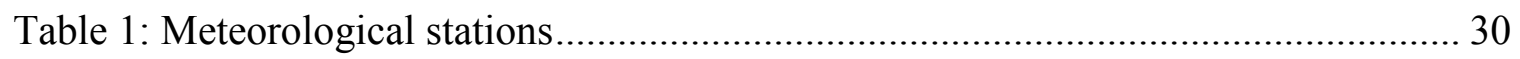

Table 2: Rainfall and distribution through the year, Buenos Aires station....................... 31

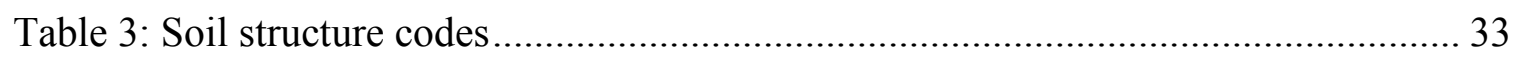

Table 4: Permeability categories codes................................................................ 34

Table 5: Soil erodibility, $K$ factor values provided in SI metric units ........................... 48

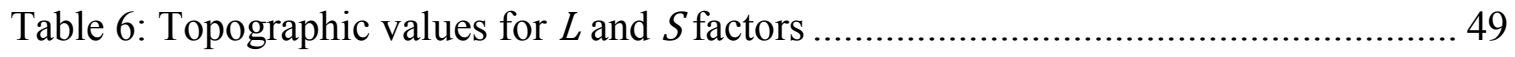

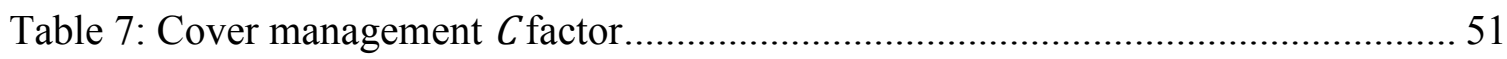

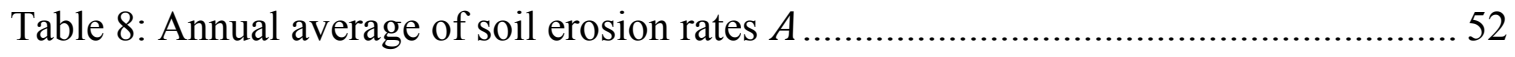

Table 9: Mean and standard deviation in comparison between communities ................. 54

Table 10: Total households per community and total interviewed ............................... 56

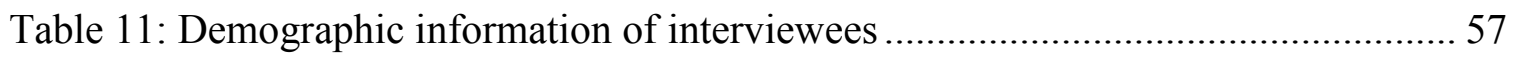

Table 12: Knowledge of what soil erosion is by gender...........................................59 
Table 13: Level of knowledge per community.

Table 14: Knowledge on the most eroded area of the community.

60

González-Morales 9 


\begin{abstract}
Soil erosion is a natural geological phenomenon resulting from removal and transportation of soil particles by water, wind, ice and gravity. As soil erosion may be affected from cultural factors as well. The physical and social phenomena of soil erosion are researched in six communities in the upper part of Rio Grijalva Basin in the vicinity of Motozintla de Mendoza, Chiapas, Mexico. For this study, the USDA RUSLE model was applied to estimate soil erosion rates in the six communities based on the available data. The RUSLE model is based on soil properties, topography, and land cover and management factors. These results showed that estimated soil erosion rates ranged from a high of 2,050 metric ton $\mathrm{ha}^{-1} \mathrm{yr}^{-1}$ to a low of 100 metric ton $\mathrm{ha}^{-1} \mathrm{yr}^{-1}$. A survey concerning knowledge, attitudes and practices (KAP) related to soil erosion was also conducted in all 236 households in the six communities. The main findings of the KAP survey were: $69 \%$ of respondents did not know what soil erosion was, while over $40 \%$ of the population perceived that hurricanes are the biggest factors that cause soil erosion, and about $20 \%$ of the interviewees said that the landslides are the consequences of the soil erosion. People in communities did not perceive cultural factors as important in conservation efforts for reduce vulnerability to erosion; therefore, the results obtained are suggested to be useful for informing efforts to educate stakeholders.
\end{abstract}




\section{Chapter I. INTRODUCTION}

\subsection{Definition and importance of soil erosion}

Currently, the environment is daily threatened by many factors. One major environmental problem is soil erosion. The problems caused by soil erosion include but not limited to loss of productivity, soil degradation, and decrease in water quality. Erosion is a natural geological phenomenon resulting from removal and transportation of soil particles by water, wind, ice and gravity (Lal 1995; Gitas et al. 2009) .This project will focus on soil erosion being a complex phenomenon governed by factors such as erosion by rainfall, soil erodibility, topography, land use and conservation measures (Lopez-Vicente 2007), and will assess an agricultural community's knowledge, attitudes and practices associated with controlling the soil erosion. The major factors that cause soil erosion are human activities such as urbanization, road construction, deforestation, intensive livestock grazing, and agriculture (Brooks et al. 2003). There are three main erosion processes: surface erosion, gully erosion and soil mass movement. Surface erosion depends on the amount and type of cover vegetation that protects it, on the intensity on forces from raindrop splash, wind, and overland flow and from inherence of soil's physical, slope gradient ( which water flows into channels over short periods, and removes soil from a narrow area to considerable depth. Soil mass movement can be defined as dislodgement and downslope transport of soil and rock material as a unit under direct gravitational stress. This process includes two types of movements; slow displacements and rapid movements. The first movements are creep and solifluction, and second movement is that 
which occur in phenomenon such as landslides. In addition agents such as water, ice and air play important roles in the process (America 2012)

\subsection{Prediction of soil loss}

Many scientists have been interested in estimating soil erosion by applying different models, not only to estimate the amount of soil loss caused by soil erosion and but also estimate the risk to the population which lives around those areas. There are several models used to measure the soil erosion caused by the action of water; one is the Universal Soil Loss Equation (USLE), an empirical erosion model that computes average annual soil losses.

The USLE model uses rainfall data, soil type, topography, vegetation cover, and conservation practices in estimating soil erosion. Some advantages for using USLE include; the comprehensive database on which it was developed and its simplicity. This model, however, has limitations that hinder it as a method for estimating soil erosion. One of the primary limitations is that some of the factors such as the rainfall are not accurately available in some places outside the United States (Wischmeier W. H. and Smith 1978). As an empirical model, it also does not provide sediment transport and physical separation processes. USLE application in pastures is limited and it is based on management uniforms, ground slope, soil and cultivation. And the last limit is that the USLE was not created for estimation of sediment yield in a complex basin (oose 1996). Despite these limitations, USLE was incorporated into other improved technologies for prediction to soil erosion. 
Modifications were made to the ULSE model to take into consideration the limitations discussed earlier. A model that comes from the original USLE, modified for use in rangelands and forest environments, is the Modified Universal Soil Loss Equation (MUSLE) model. This model can be used in a different land use and management strategies to quantify the potential erosion. MUSLE has been developed for estimating the sediment load produced by each storm, which takes into account not only rainfall erosivity but also the volume of runoff (Williams 1990).

However, invalid interpretations can be made if there is failure in the understanding of the equation of the MULSE model. It is also much like USLE in that the modified universal soil equation requires an estimated value for rain factor. This is a specific condition where the records for intensity of rainfall have to be analyzed because often they are not available (Brooks et al. 2003). Consequently, the MUSLE model presented significant weaknesses in terms of the conditions for its application and the accuracy of the results obtained.

The Revised Universal Soil Loss Equation (RUSLE) model was developed by Wischmeier and Smith in 1978, and it also was taken from USLE model, to address these weaknesses in the USLE model such as temporal changes in soil erodibility and plan factors. Studies have shown that the application of RUSLE model using Geographic Information Systems to be a useful and efficient tool for assessing and mapping the vulnerability of soil erosion in watershed (Yue-qing et al. 2008). This model has been widely used in predicting soil erosion loss, also, it can be applied in different situations, including forest, rangeland, and disturbed areas. 
The RUSLE model has been used in addressing problems, therefore RUSLE2 was introduced as an improved computer based, applied to degraded sites in urban areas. RUSLE2 was updated by United States Department of Agriculture-Agricultural Research Services (USDA-ARS). This model owns a customized database; however it is mostly applied by urban environments ( $\underline{\text { Scharff 2005) }}$, RUSLE is still more applied to rural areas.

The Water Erosion Prediction Project model (WEPP) (Renard et al. 1997) was developed by United States Department of Agriculture-Agricultural Research Services (USDAARS). WEPP is a model that predicts soil and deposition rather than average of soil loss. This model is applied extensively to accounting topography, cropping and management, soil properties and sediment and erosion process (Tiwari et al. 2000). The WEPP model's physical base therefore can be used for small watersheds or in hill slope applications. The WEPP model simulates many of the physical processes important in soil erosion, including infiltration, runoff, raindrop and flow detachment, sediment transport, deposition, plant growth, and residue decomposition (Pieri et al. 2007). WEPP requires data such as climate (daily amount of precipitation, solar radiation, wind speed and direction), soil (albedo, soil water content, hydraulic conductivity, rock content), slope (slope length, steepness and profile aspect), and plant/management (land use) and type and dates of residue management are required ( $\underline{\text { Renschler 2003). }}$.

The Soil and Water Assessment Tool (SWAT) model is a physically based, continuous time, long-term simulation, deterministic model that originated from agricultural models. 
The SWAT model is known as one of the most recent models developed by the United States Department of Agriculture - Agricultural Research Services (USDA-ARS) and Agricultural Experiment Station in Temple, Texas. SWAT components are; hydrology, weather, sedimentation, soil, temperature, crop growth, nutrients, pesticides, and agricultural management (Jain et al. 2010). This model uses inputs such as weather variables, soil properties, topography, and vegetation and land management practices occurring in the catchment. The SWAT model has been applied worldwide, and its hydrologic components have been successfully tested by researchers in watersheds with various climate and terrain characteristics (Zhang et al. 2008).

\subsection{Model selection for this study}

After comparing several models that have been used for soil loss erosion prediction, the RUSLE model is chosen. This model has good acceptance and wide use, is simple and easy to parameterize, and requires less data and time to run than most other models (Fernandez et al. 2003). Also, though newer models like SWAT and WEPP have been developed, the RUSLE model was used in this model because the newer models require other data that were not available in the project area at the time of this study.

Wischmeier (1976) explains that the limitations encountered in USLE also encountered in RUSLE, however the RULSE has some improvements over the USLE model, which in itself is a powerful model for predicting soil erosion. There are many limitations, however first; both models estimate soil loss average annually average annual by sheet and rill erosion. RUSLE model predicts soil loss estimations rather than total soil loss data, these estimations are not for specific precipitation events being long terms. 
However, it does not estimate ephemeral gully erosion and also the estimation of the sediments accumulated downstream even this model does not predict information about the characteristics of the sediment. In addition, this empirical model does not consider explicit fundamental equations based on hydrological and erosion processes (Renard et al. 1991).

\subsection{Knowledge, Attitudes and Practices as perceptions of soil erosion}

The assessment of knowledge, attitudes and practices perceptions leads to the understanding of the relationship between people and environmental issues, the role of

the human dimensions and their nature resource, perceptions of the importance of environmental issues, and the willingness of the community to participate in reducing environmental impacts. A KAP survey can be defined as a representative study to collect information on specific population on what is known, what they believe, and what they do or are been doing in relation to a particular topic (WHO 2008). The KAP survey has been used since 1950 in family planning and population studies. It provides information on knowledge, attitudes and practices, and is straightforward to design and interpret (Launiala 2009). The KAP survey methodology has been mostly utilized for health researches; however it has also been used in environmental problems, especially in developing countries (Walker 2008).

The knowledge portion of a KAP survey captures what interviewees know about a particular subject. In this study, it is used to assess people's knowledge about soil erosion. This knowledge can include facts (such as what causes erosion) as well as local knowledge (such as where the erosion is occurring in their community).

González-Morales 16 
It also represents the perception of the people's behavior and the depth and level of the knowledge of the people. In this study the knowledge portion of the survey is used for assessing the extent of the community's knowledge about the subject being studied (Launiala 2009). Attitudes refer to people's feelings about a phenomena a problem or an object (Launiala 2009). Attitudes also explain the options that a subject can take in a practice and practices refer to behaviors that are observable actions.

KAP surveys have been done before on soil erosion with the purpose of assessing what farmers know about soil erosion, what they perceive to be main causes and what they current practices. The main goal was to assess their soil conservation practices, and to improve these practices, so as to reduce the amount of erosion that occurs after high rainfall, especially in areas with steep slopes (García-Barrios et al. 2009). These surveys also have been applied as a strategy for analyzing, knowledge, attitudes and practices on land degradation for the purpose of determining how best to generate awareness of the problems.

In a study KAP survey of communities in Grenada that examined the knowledge, attitudes and practices of interviewees in regard to soil degradation, researchers determined that $64 \%$ of the entire population did not know about the problem (Jong et al. 1999). In KAP study that was undertaken to identify indicators for erosion risks on Africa, the interviewees indicated that lands with hill slopes need more attention in terms of conservation practices, because the steep slopes have shown more damaged areas than flat slopes (Flamenco-Sandoval et al. 2007). 


\subsection{Grijalva River watershed}

The Grijalva River basin is located in the south of Mexico; it begins in Guatemala and crosses the states of Chiapas and Tabasco. Climatic conditions in the upper (ChiapasGuatemala) and medium (Chiapas-Oaxaca) basin has an annual average precipitation range between 1200 and $1700 \mathrm{~mm}$, the lower part of the basin (Tabasco) has an annual average precipitation greater than $4000 \mathrm{~mm}$. The areas adjacent to streams and their tributaries and effluents are prone to flooding (Gutierrez- Horacio Rubio and Triana 2006).

The Grijalva basin soils have suffered degradation in more than half the basin area in terms of chemical quality, particularly fertility, which declined due to physical degradation (erosion) (Colegio de Postgraduados 2002), with negative implications for rural development and social processes (García-Barrios et al. 2009). The degradation of the vegetation cover, soil and water quality is severe starting from the upper through the medium and down to the low basin (Bueno et al. 2007). The upper Grijalva Basin has had a severe change in land use resulting in the loss of up to 50\% of forest area (Jong et al. 1999; Cayuela et al. 2006; Flamenco-Sandoval et al. 2007; Sánchez-Núñez et al. 2012).

In the basin hydro-meteorological phenomenon are constant, which the downstream or low part of the stream located in Tabasco state has high vulnerability to flooding since the lack of environmental studies in the Chiapas and Guatemala to mitigate the water quality that has been contaminated from mining pollution, sewages and disposal waste (Garcia 2011). 
Motozintla de Mendoza, Chiapas is one of the cities located in the upper part of the Grijalva basin. This city has experienced environmental problems such as flooding and landslide due to soil erosion. The Motozintla municipality is considered at a high risk for floods, winds, lightning and landslides. The annual average temperature is from 14 to $24^{\mathrm{O}} \mathrm{C}$, annual precipitation follows a pattern from north to south with values from 800 to $>5000$ (Gordillo 2009).

The city has experienced many storms. However, two of them have been especially important, because of their destructiveness: Hurricane Mitch, which occurred from September 6 to 12 in 1998, and Hurricane Stan, which occurred from October 4 to 8 in 2005. Hurricane Mitch caused the overflow of 50 rivers in the Chiapas state. One hundred isolated communities and 10 municipalities were affected by the flooding problem. One of those municipalities was Motozintla de Mendoza, reported as a municipality with disasters due to landslides and overflowing. The rocks and mud brought from the landslides invaded many houses at a height of about three meters (Suarez-Diaz 2006).

Hurricane Stan caused the overflow of 72 rivers in Chiapas State, affecting 45 municipalities of 118 municipalities in Chiapas. Motozintla de Mendoza was one municipality where 3,000 houses were swept by landslides. The Xelaju tributary usually has an approximate width of 3 meters and a height of more than 2 meters. As a result of Hurricane Stan, the Xelaju tributary was transformed into a river width of 100 meters and a height of more than 6 or 8 meters (Suarez-Diaz 2006). 


\subsection{Motivation and objective}

Motozintla de Mendoza is an area very susceptible to soil erosion because of the environmental degradation. Some of the environmental problems present in Motozintla are: pollution caused by the disposal waste, lack of quality sewage treatment, deforestation, and especially that the municipality is located in a high risk area. The main environmental issue is deforestation: The felling of trees in the region increases every year because people are not aware the resulting problems and because of the financial incentives from the wood obtained from trees leading to people making illegal sawmills in the area.

The general objective of this report is to assess soil erosion and understand the relationship between knowledge, attitudes and human practices to control the problem in six communities in the vicinity of Motozintla de Mendoza, Chiapas. A physical and sociological assessment of the vulnerability to soil erosion in this area will highlight the areas with environmental problems, and assess what people understand about the situation. The generated information will be useful for decision-making in the design of forest restoration in the specific communities and in promoting awareness and conservation practices in the specific areas.

González-Morales 20 


\section{Chapter II. STUDY AREA}

This research was developed in six communities belonging to the Sierra Madre region of Chiapas within the upper part of Grijalva river watershed in the municipalities of Motozintla de Mendoza and Mazapa de Madero. The communities are located near $15^{\circ}$ $22^{\prime}$ north latitude and $92^{\circ} 15^{\prime}$ west longitude at an altitude of 1,260 meters above sea level or on $15^{\circ} 23^{\prime}$ north latitude and $92^{\circ} 11^{\prime}$ west latitude at an altitude of 1,100 meters above sea level. These two municipalities are located in Chiapas State in the south of Mexico as shown in Figure 1. The six communities are as follows:

Benito Juarez Centro $15^{\circ} 21^{\prime} 57^{\prime \prime}$, north latitude, $92^{\circ} 18^{\prime} 45^{\prime \prime}$ west longitude, Carrizal Centro $15^{\circ} 24^{\prime} 09^{\prime \prime}$ north latitude, $92^{\circ} 17^{\prime} 50^{\prime \prime}$ west longitude, Barrio Vicente Guerrero $15^{\circ} 22^{\prime} 56^{\prime \prime}$ north latitude, $92^{\circ} 18^{\prime} 38^{\prime \prime}$ west longitude, Barrio La Union $15^{\circ} 24^{\prime} 32^{\prime \prime}$ north latitude , $92^{\circ} 17^{\prime} 26^{\prime \prime}$ west longitude , Barrio Plan Grande $15^{\circ} 23^{\prime} 45^{\prime \prime}$ north latitude , 92 $17^{\circ} 53^{\prime \prime}$ west longitude belonging to Motozintla de Mendoza municipally and Poblado Cambil $15^{\circ} 23^{\prime} 10^{\prime \prime}$ north latitude, $92^{\circ} 10^{\prime} 06^{\prime \prime}$ west longitude that belongs to Mazapa de Madero municipality (all the communities are showed in the Figure 1 as red dots).

The geology in the upper part of the watershed contains a mixture of rock formation among sedimentary and metamorphic rocks followed by igneous rocks (Carfantan 1977). There are three fault lines around this area. One of the fault lines culminates in the Sierra Madre, another in the Tacana volcano, and the last runs through Central America. These faults have produced a mountainous topography, which in addition to the high rainfall generates runoff thus making the Grijvala River basin, makes the area around Motozintla highly vulnerable to erosion. In addition this study area is also prone to landslides which 
also results in land and soil loss, however landslides results in more mass wasting as well as loss of lives.

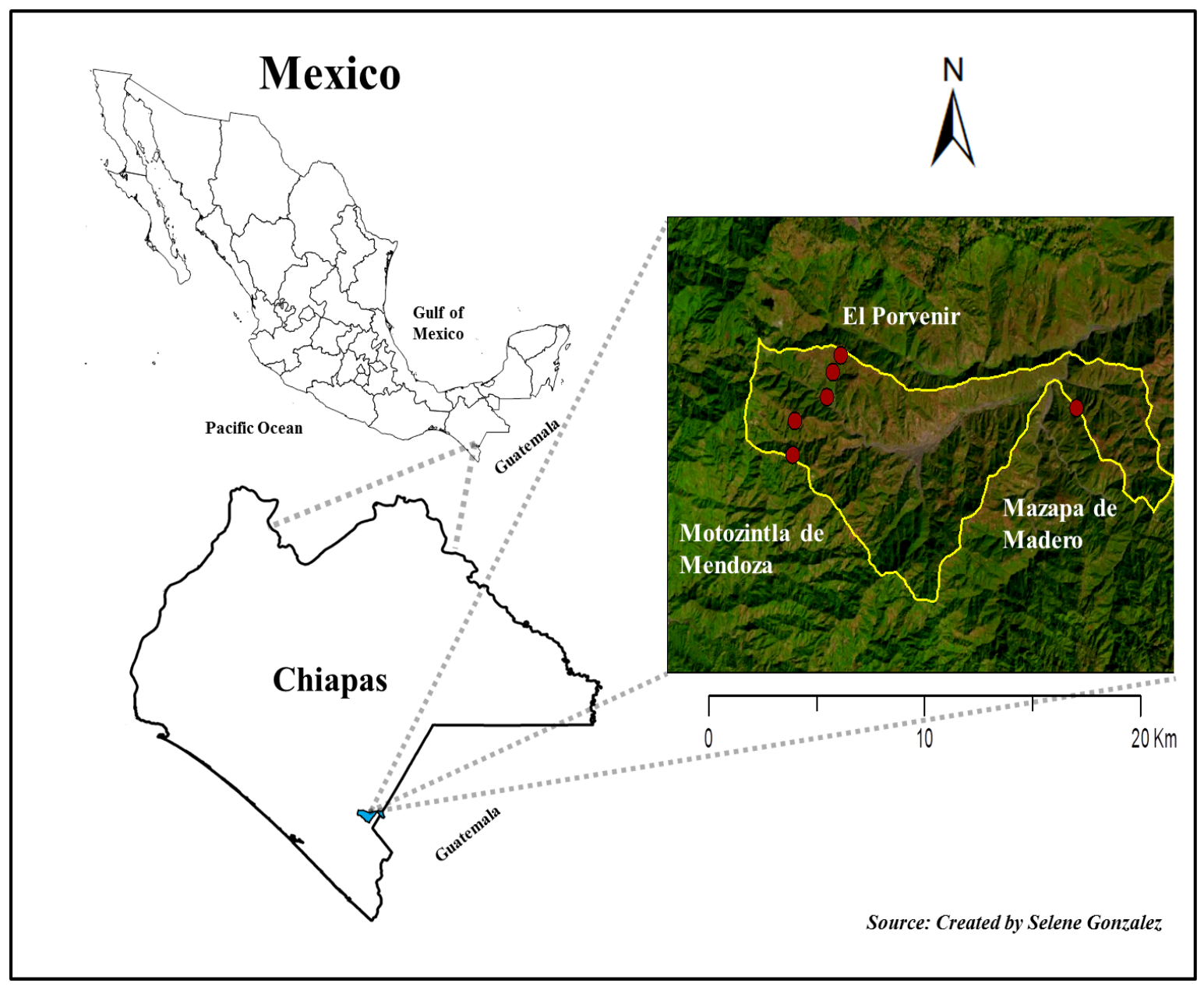

Figure 1: Study area -Motozintla de Mendoza municipality

The total population in the entire municipality of Motozintla de Mendoza counted in 2010 indicated 69,119 individuals, where 51\% from the total are female, with the total number of households being 13,798 (INEGI 2010). Mazapa de Madero municipality has a total population of 7,793 individuals, where $50 \%$ are females in a total of 1462 households. 
All the communities examined in this study have preschools, elementary schools, but only some of them have middle schools and high schools in their own communities. In communities without middle schools and high schools, students either travel to the closest community or to Motozintla de Mendoza city or simply do not continue their education. According to the 2010 census the average education level in the entire municipality is about 6.1 , which is just above elementary, and 101 individuals from the entire population in the municipality received a degree from a university (INEGI 2010). Some people in these communities prefer to drop their studies because of the need to work and to help their family with expenses. For people are interested in obtaining a higher education such as university professional education, Students have to travel to Motozintla city or in other municipalities to continue education, and they have to pay rent or live with their relatives close to where they study.

The major economic activity in the communities is agriculture, consisting mainly of corn and beans crops and for cattle rearing. According to the 2010 census in the Motozintla de Mendoza municipality in 2009, in a total of 27, 422 hectares used for planting, 11,094 hectares of land were occupied by corns crops and 1,216 hectares by beans (INEGI 2010). Many inhabitants also have a small farm close to their house with vegetables such as cabbage, cauliflower, cilantro and onion. Most of the agricultural activities are for their own consumption and the remainder harvested and sold in Motozintla de Mendoza city where other municipalities participate buying their food. However, the agricultural activities have negative results in overexploitation of land leading soil erosion. 
This region is also a region with high topography as a result to that; risks in economic development by low productivity in their lands are faced. In addition to that, the severe exploitation of forest, mainly species such as pines, cypresses, oaks and mahoganies, together with pronounced slopes has helped to increase the soil erosion problem. 


\section{Chapter III. Part 1. METHODOLOGY: RUSLE MODEL}

\subsection{Soil sampling and analysis}

In order to use the RUSLE model, the soil properties are needed in order to obtain the K factor (See 3.2.2 section). Soil sample collection took place in the six communities of Motozintla de Mendoza Chiapas (Figure 1) during July to August 2011.

Permission for working in these communities was obtained from the local authorities from ECOSUR, San Cristobal de Las Casas, Chiapas some months prior to the fieldwork. The soil sampling methodology was designed by the Colegio de la Frontera Sur (ECOSUR) for the Management and Sustainable Strategies for Regional Development's project in the Grijalva basin. The methodology was applied by a team which consisted of technicians from ECOSUR, two other students and the author.

Identification of specific sites for sampling was carried out by the members of the local community, the teams from ECOSUR, and the author during a field trip, taking into account the areas of high priorities and potential for soil erosion and subsequent forest restoration (Figure 2). Most of plots were 'Astilleros' (Astilleros is a local common name of the communal land ruled by the Ejidos authorities) with different percentages of canopy cover. We found one of the plots had been previously burnt, followed by croplands, a school plot and communal pastures. In Latin America, ejido is a Spanish term that means "commons" when used to describe agrarian practices (Blau and Moncada $\underline{2006})$. 


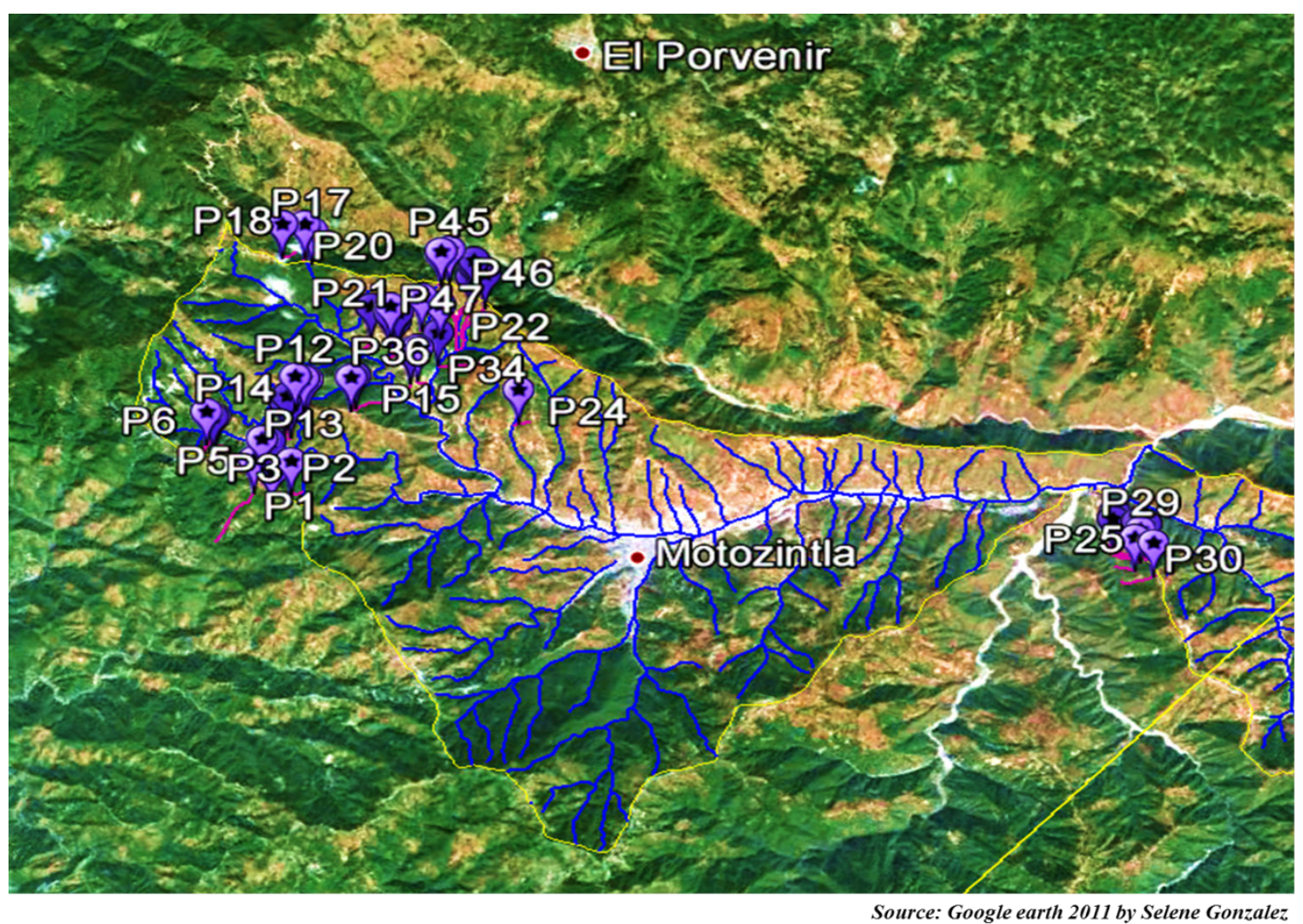

Figure 2: Plot locations in the communities

The methodology for sampling was to select eight circular plots with a measure $1000 \mathrm{~m}^{2}$

(Ramírez-Marcial et al. 2001) that represent the variability land use in the communities

(Figure 3).

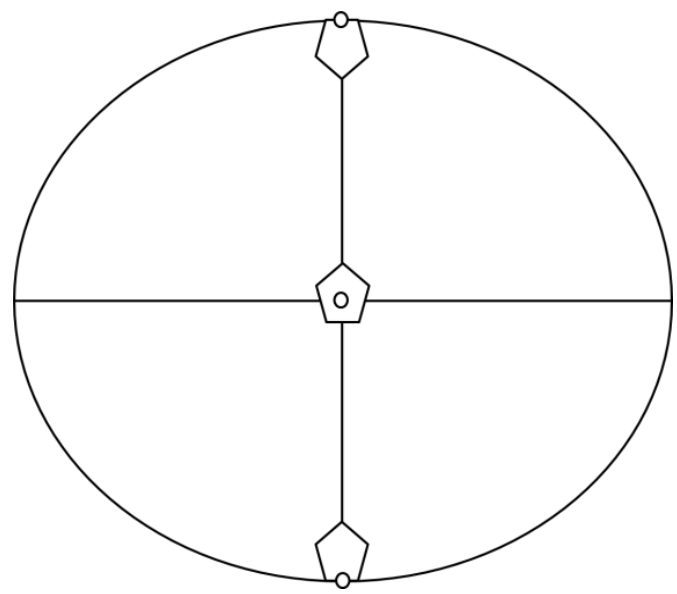

Figure 3: Sampling site design

González-Morales 26 
For each plot six soil samples were taken by randomly picking three points in a way that these three points aligned in a straight line. For each point, five surrounding points are further marked and two samples are taken from each of the five marked points. The two samples for each point are samples taken from a depth of $0-20 \mathrm{~cm}$ and $21-40 \mathrm{~cm}$ respectively. All the five $0-20 \mathrm{~cm}$ samples for each of the three aligning points are combined together and also the five $21-40 \mathrm{~cm}$ samples, resulting in a total of six samples in all. This was done to ensure a proper representation of the overall soil sample. The soil sampling in each community obtained was a total of 48 soil samples, 24 to the first 0 $20 \mathrm{~cm}$ and 24 of the $21-40 \mathrm{~cm}$ depth. At the end of the fieldwork, the total of sampling within the six communities was in total 288 soil samples (6 communities, 8 plots per community and 6 samples each plot).

The soil samples were dried, sieved and analyzed in the ECOSUR soil laboratory in San Cristobal de las Casas, Chiapas, to analyze the following physicochemical properties: Texture by the Bouyoucos procedure, method from AS-09, NOM-021-2000 RECNAT, and organic matter by the method of Walkley and Black, AS-07, NOM-021-RECNAT2000 (SEMARNAT 2002).

\subsection{RUSLE}

Soil erosion rates in the RUSLE model are calculated as follows (Renard et al. 1997)

$$
\mathrm{A}=\mathrm{R} * \mathrm{~K} * \mathrm{~L} * \mathrm{~S} * \mathrm{C} * \mathrm{P}
$$

Where:

$$
R=\text { is the rainfall erosivity expressed in } \mathrm{MJ} \mathrm{mm} \mathrm{ha}{ }^{-1} \mathrm{~h}^{-1} \mathrm{yr}^{-1} \text {, }
$$


$K=$ is the susceptibility of soils to erosion, expressed in ton acre ${ }^{-1}$, U.S Units, (ton ha h ha ${ }^{-1} \mathrm{MJ}^{-1} \mathrm{~mm}^{-1} \mathrm{SI}$ metric units)

$L=$ is the length of slope (dimensionless factor),

$S=$ is magnitude of the slope (dimensionless factor),

$C=$ is the cover and crop management (dimensionless factor),

$P=$ is the conservation practices (dimensionless factor) and

$A=i s$ the average soil loss for the period of time represented generally at 1 year expressed in ton $\mathrm{ha}^{-1} \mathrm{yr}^{-1}$.

\subsubsection{Rainfall erosivity factor $(R)$}

This is defined as the rainfall erosion index plus a factor for any water where runoff is significant. The rainfall runoff erosivity factor is the sum of all the energies of the entire annual erosivity event with its maximum intensities over 30 minutes $\left(\sum_{1}^{n}(\mathrm{E} * \mathrm{I} 30)\right)$. Rainfall data must be the average determined during many years. The United States has data for $R$ factor that has been calculated for at least 10 years. However, most countries do not have this data available. With the need to quantify the energy and maximum intensity, it is recommended to make use of gauges to be able to know almost exactly the hourly precipitation dynamics.

The normal equation used and applied for Renard et al. (1994) for this factor is:

$$
R=\frac{\sum_{i=1}^{j}(E I 30) i}{N}
$$

González-Morales 28 
Where:

$R=$ is the rainfall erosivity factor $\left(\mathrm{MJ} \mathrm{mm} \mathrm{ha}{ }^{-1} \mathrm{~h}^{-1} \mathrm{yr}^{-1}\right)$

$(E I 30) i=$ is the intensity for 30 minutes for each storm $\left(\mathrm{MJ} \mathrm{mm} \mathrm{ha} \mathrm{mb}^{-1}\right) i, j=$ is the number of storms in an $N$ year period.

However, in countries where the meteorological stations available do not have the data required to use the formula above, alternative methodologies have been proposed. One of the methods commonly used in such circumstances is the application of the Fournier Index ( $\underline{\text { Fournier 1960) }}$ being $F=\frac{\mathrm{p}^{\wedge} 2}{\mathrm{P}}$, where $p$ is the average of the highest rainfall of the month and $P$ is the annual average rainfall. A study in Morocco, Africa using the same data that Fournier applied, Arnoldus, (1980) found a correlation with $R$ in equation (2) of $r^{2}=0.83$ using Modified Fournier Index for rainfall factor expressed in the next equation.

$$
\mathrm{Fmod}=\sum_{i=1}^{12}\left(\frac{p i^{\wedge} 2}{P}\right)
$$

Where:

$$
\begin{aligned}
& \text { Fmod }=\text { Modified Fournier Index (mm) } \\
& p i=\text { Average Monthly precipitation } \\
& P=\text { Average Annual Precipitation }
\end{aligned}
$$

The Modified Fournier Index equation (3) was calculated from a set of monthly average rainfall from 29 years. The resulting correlation is

$$
R=95.77-6.081 F+0.4770 F^{2}
$$

González-Morales 29 
This equation also applicable when one has the Modified Fournier Index. According to (Renard and Freimund 1994) these equation was found a relation with the Modified Fournier Index expressed in $\mathrm{mm}$ and $R$ factor expressed in units of $\mathrm{MJ} \mathrm{mm} \mathrm{h}$ yr. This equation is assumed that when Modified Fournier Index calculated is more than $55 \mathrm{~mm}$ or greater this equation is suggested.

The average rainfall was obtained from Fomento Regional para el Desarrollo Científico, Tecnológico y de Innovación (FORDECYT); however the original sources were obtained from Consejo Nacional del Agua (CONAGUA). Daily data from 29 years were obtained within five meteorological stations (Table1 and Figure 4). However, the Buenos Aires station was chosen for this study because the altitude of this station was closest to that of the study area communities.

Table 1: Meteorological stations

\begin{tabular}{|c|c|c|c|c|c|c|c|c|c|c|}
\hline $\begin{array}{l}\mathrm{N}^{\circ} \\
\text { station }\end{array}$ & Station & State & Municipality & $\begin{array}{l}\text { Lat. } \\
\text { N }\end{array}$ & & & $\begin{array}{l}\text { Lon } \\
\text { W }\end{array}$ & & & $\begin{array}{l}\text { Altit. } \\
\text { MASL }\end{array}$ \\
\hline 7014 & Belisario Dguez. & Chis & Motozintla & $15^{\circ}$ & $17^{\prime}$ & $00^{\prime \prime}$ & $92^{\circ}$ & $22^{\prime}$ & $00^{\prime \prime}$ & 660 \\
\hline 7067 & $\begin{array}{l}\text { Amatenango de } \\
\text { la Fra. }\end{array}$ & Chis & $\begin{array}{l}\text { Amatenango de la } \\
\text { Fra. }\end{array}$ & $15^{\circ}$ & $26^{\prime}$ & $01 "$ & $92^{\circ}$ & $06^{\prime}$ & $51^{\prime \prime}$ & 850 \\
\hline 7119 & Motozintla & Chis & Motozintla & $15^{\circ}$ & $22^{\prime}$ & 00 & $92^{\circ}$ & $15^{\prime}$ & $30^{\prime \prime}$ & 1,210 \\
\hline $7333 *$ & Buenos Aires & Chis & Motozintla & $15^{\circ}$ & $19^{\prime}$ & $57 "$ & $92^{\circ}$ & $16^{\prime}$ & $03 "$ & 1,720 \\
\hline 7339 & El Porvenir & Chis & El Porvenir & $15^{\circ}$ & $27^{\prime}$ & $26^{\prime \prime}$ & $92^{\circ}$ & $16^{\prime}$ & $00^{\prime \prime}$ & 2,730 \\
\hline
\end{tabular}




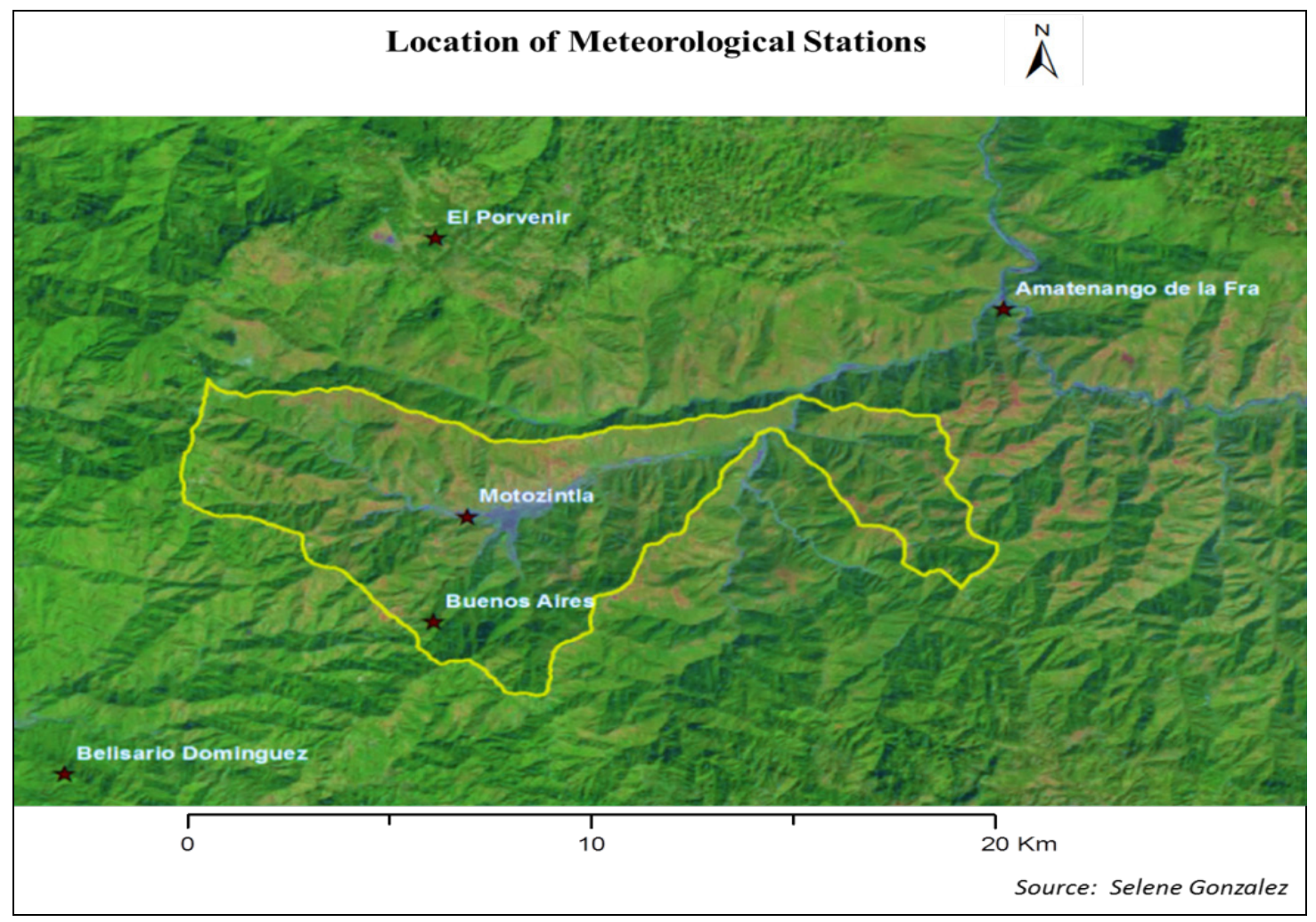

Figure 4: Meteorological stations

The general average data obtained in Buenos Aires station in a period from 1980 to 2009 is shown in Table 2.

Table 2: Rainfall and distribution through the year, Buenos Aires station

\begin{tabular}{lcc}
\hline Month & $\begin{array}{c}\text { Average } \\
\text { precipitation (p) mm }\end{array}$ & $\begin{array}{c}\text { Percentage } \\
\mathbf{\%}\end{array}$ \\
\hline Jan & 2.72 & 0 \\
Feb & 5.16 & 0 \\
Mar & 10.70 & 1 \\
Apr & 21.15 & 2 \\
May & 78.55 & 7 \\
Jun & 250.44 & 21 \\
Jul & 188.08 & 16 \\
Aug & 207.09 & 17 \\
Sep & 253.20 & 21 \\
Oct & 147.98 & 12 \\
Nov & 20.60 & 2 \\
Dec & 5.17 & 0 \\
Total & 1190.84 & 100 \\
Source: Comision Nacional del Agua (CONAGUA)
\end{tabular}

González-Morales 31 


\subsubsection{Soil erodibility factor $(K)$}

This is the soil-loss rate per erosion index unit for a specified soil as measured on a standard plot; it is defined as a $72.6 \mathrm{ft}(22.1 \mathrm{~m})$ length of uniform $9 \%$ slope in continuous clean-tilled fallow. This factor shows the influence between soil profile characteristics and soil properties on soil loss (Wischmeier W. H. and Smith 1978; Romkens 1985).

The soil erodibility $\mathrm{K}$ factor can be calculated in two different ways, with an equation or directly by a soil-erodibility nomograph developed by Wischmeier et al. (1971). However, both procedures need to be done taking into consideration some chemical properties of the soil such as; texture, organic matter, soil structure and permeability.

The equation used is:

$$
K=\left(\frac{1}{7.59}\right)\left[2.1 * 10^{-4}(12-O M) M^{1.14}+3.25(s-2)+2.5(p-3)\right] / 100
$$

Where:

$K=$ is the soil erodibility factor expressed in ton acre $^{-1}$ per erosion index unit with U.S units of ton acre $\mathrm{h}$ (hundreds of acre ft-tonf in) ${ }^{-1}$. However, in this case the units were converted to SI metric units (ton ha $\mathrm{h} \mathrm{ha}^{-1} \mathrm{MJ}^{-1} \mathrm{~mm}^{-1}$ ), therefore, a division of the right side of this with the factor 7.59 will yield $K$ values.

$O M=$ is organic matter $\%$

$M=$ is the product of the size fractions (\% of modified silt or the $0.002-1.0 \mathrm{~mm}$ size fraction)*(\%silt+\%sand), the $\%$ of modified silt was not found; $\%$ of silt was taken instead.

$s=$ is the structure code 
$p=$ is the permeability code

7.59 = factor to account for conversion from English units to SI metric units

The glossary in the documentation of RUSLE in 2005 defines these properties as follows (Foster 2005). Texture is the distribution of the particles such as sand, silt and clay in the soil mass exposed to erosion. It can be determined using the Bouyoucos method based on AS-09, NOM-021- RECNAT-200 (SEMARNAT 2002). Organic matter is defined as the amount in percentages of soil organic matter content in unit plot condition. It can be analyzed by the method of Walkley and Black based on AS-07, NOM-021-RECNAT2000 (SEMARNAT 2002). Soil structure refers to the aggregates of soil particles in soil mass. According to Agriculture Handbook number 537 and RUSLE Agriculture Handbook number 703, the categories and codes applied are only four as shown in the Table 3.

Table 3: Soil structure codes

\begin{tabular}{cc}
\hline Codes & Soil structure \\
\hline 1 & Very fine granular \\
2 & Fine granular \\
3 & Med or coarse Granular \\
4 & Blocky, platy or massive \\
Source: Agriculture Handbooks, USDA
\end{tabular}

Data for soil structure in this factor was obtained from RUSLE 2 program database from USDA (United States Department of Agriculture), comparing soil particles with the aggregates. Permeability is defined as the index potential of the soil to generate runoff in the unity of a plot. These values are shown as categories in the Table 4 where, according to (Wischmeier W. H. and Smith 1978) permeability is assigned 6 different codes according to the rate of permeability. 
Table 4: Permeability categories codes

\begin{tabular}{cc}
\hline USLE/RUSLE Codes & Permeability categories \\
\hline 1 & Rapid \\
2 & Moderate to rapid \\
3 & Moderate \\
4 & Slow to moderate \\
5 & Slow \\
6 & Very Slow \\
\hline
\end{tabular}

Source: Agriculture Handbooks, USDA

The data calculation was made using excel for all the data of $K$ factor recorded including $\%$ of organic matter, $\%$ sand, $\%$ of silt, $\%$ of clay, textural name. The average of the 6 samples for each plot was calculated, resulting in 48 averaged values of the $K$ factor.

\subsubsection{Slope length factor $(L)$}

Slope length factor is the ratio of soil loss from the field slope length to soil loss from a $72.6 \mathrm{ft}$ length under identical conditions. The slope length can be explained as the horizontal distance where the origin of overland flow starts and to the point where the slope gradient decreases enough and the deposition begins or where runoff is concentrated to in a defined channel (Wischmeier W. H. and Smith 1978).

In order to estimate slope length factor $(L)$, the following equation is used (McCool et al. 1997).

$$
L=\left(\frac{\lambda}{72.6}\right)^{\mathrm{m}}
$$

Where:

$$
\begin{aligned}
& L=\text { is the slope length factor } \\
& \lambda=\text { is the horizontal projection }
\end{aligned}
$$


$72.6=$ is the RUSLE unit plot length in $\mathrm{ft}$.

$m=$ is a variable slope exponent.

Foster et al. (1977) suggests that the exponent $m$ is related to $\beta$ as follows.

$$
m=\beta /(1+\beta)
$$

McCool et al. (1989) provides an equation for $\beta$ for conditions when the soil is suceptible to rilland interrill erosion:

$$
\beta=(\sin \theta / 0.0896) /[3.0(\sin \theta) 0.8+0.56]
$$

Where:

$$
\theta=\text { is the slope angle }
$$

Geographic information data was obtained using a GPS (global positioning system) in order to get latitudes and longitudes of each plot. The calculation of slope angles and lengths was carried out with Google Earth, using a polygon covering most part of the study layer and rivers layer of the study area provided by the Laboratory of Geographic Information and Statistics Analysis (LAIGE) in ECOSUR. Geographic locations of each plot in the communities close to Motozintla de Mendoza polygon were labeled P1, P2...P48 ( $\mathrm{P}=$ Plot , 1,2..48= consecutive plot number $)$ into Google Earth. Horizontal lines were drawn from where the deposition begins until it ends (according to McCool, et al. 1989) using the add paths tool. Each line corresponded to a slope length for the respective plot. Finally, using the Show Elevation Profile tool, the Slope length factor was measured (in feet) from uphill to downhill (see Figure 5). 

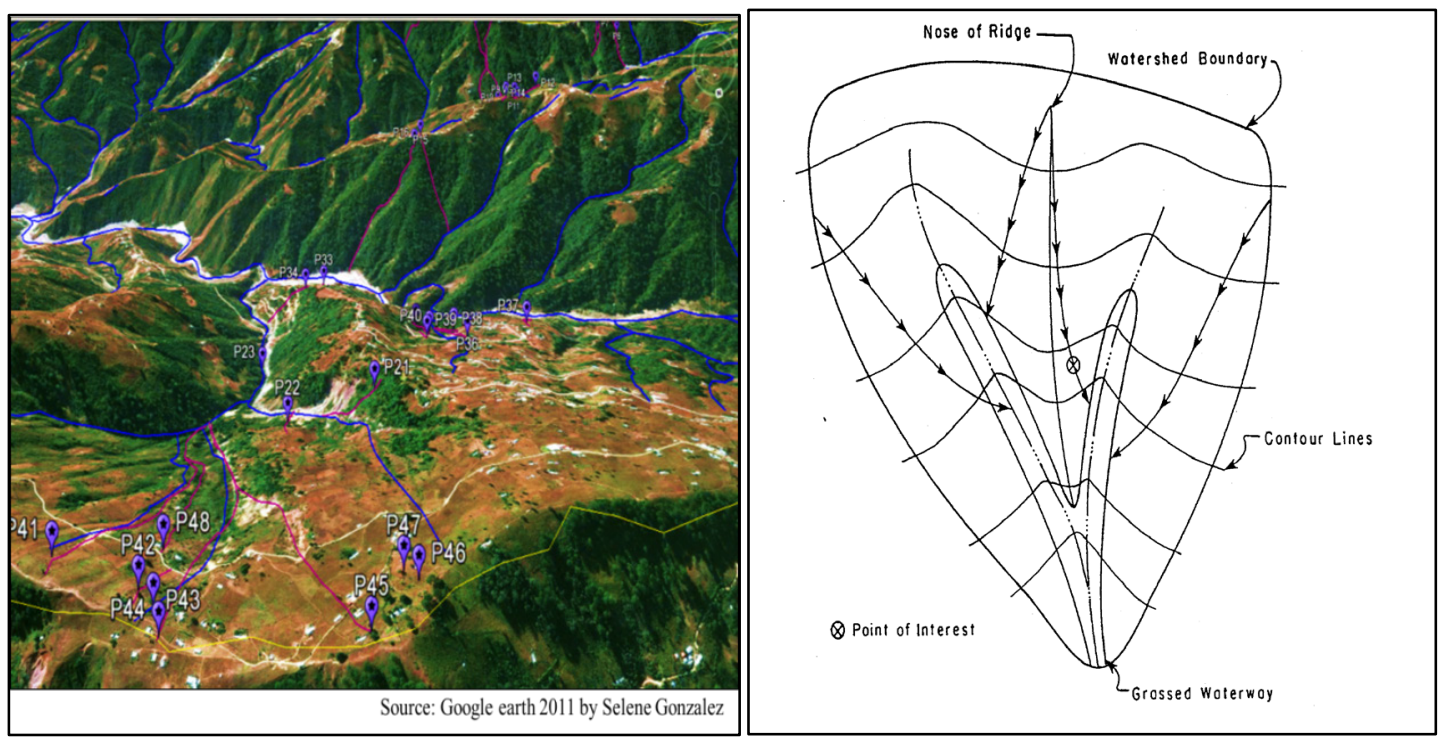

Figure 5: Length slopes measurements

USDA Handbook 703(Fig. right).

\subsubsection{Slope steepness factor $(S)$}

Slope steepness factor is the ratio of soil loss from the field slope gradient to soil loss from a $9 \%$ slope under otherwise identical conditions. The slope steepness factor reflects the influence of slope gradient on erosion. It is estimated in the field by the use of a clinometer or a similar device.

This factor which in a way similar to the slope length puts into consideration, run off from slopes; however it differs from the slope length in that its measurement does not stop when a point of accumulation is crossed. As a result, soil loss due to slope steepness increases more fast than it does for slope length; McCool et al. (1987) evaluated the slope steepness factor $(S)$ in the following way.

$$
\begin{aligned}
& S=10.8 \sin \theta+0.03 \\
& S=16.8 \sin \theta-0.50
\end{aligned}
$$


For the Slope Steepness factor, data was obtained in each plot using a clinometer (McCool et al. 1997). For this factor equation 10 was applied, all the slopes steepness calculated obtained more than $9 \%$.

\subsubsection{Cover-management factor $(C)$}

The cover-management factor is the ratio of soil loss from an area with specified cover and management to soil loss from an identical area in tilled continuous fallow. It is also used in USLE as the effect of cropping and management practices on erosion rates. Yoder et al. (1997) explain that $C$ factor estimates the effect to the average annual soil loss in a conservation plan; it also indicates the soil loss during crop rotations, construction activities or some other management plans (Renard et al. 1997) .For this factor, land use and vegetation types are very important because they support and help to reduce, control and prevent soil loss by erosion. The source of cover management factor was obtained from the fieldwork observations.

According to Yoder et al. (1997) soil loss ratios can be calculated using the equation given below:

$$
S L R=P L U * C C * S C * S R * S M
$$

Where:

$$
\begin{aligned}
& S R L=\text { is the soil loss ratio for the given conditions (dimensionless) } \\
& P L U=\text { is the prior land uses sub-factor (dimensionless), } \\
& C C=\text { canopy cover sub-factor (dimensionless), } \\
& S C=\text { the surface cover sub-factor (dimensionless), }
\end{aligned}
$$


$S R=$ the surface roughness sub-factor (dimensionless) and

$S M=$ the soil moisture sub-factor (dimensionless).

$P L U$ influences on soil erosion of subsurface due to the residual effects from previous tillage practices and from previous crops. $P L U$ ranges from $0-1$. The prior land use subfactor was computed by

$$
\left.\left.P L U=C_{f} * C_{b} * e^{\left[\left(-c_{u r} * B_{u r}\right)+\left(c_{u s} * \frac{B_{u s}}{C_{f}}\right)\right.}\right)\right]
$$

Where:

$C_{f}=$ is the soil surface soil consolidation (dimensionless),

$C_{b}=$ is the relative effectiveness of surface residue in consolidation (dimensionless),

$c_{u r}=$ is defined as the calibration coefficients indicating the impacts of the subsurface residues (acre in $\mathrm{lb}^{-1}$ ),

$c_{u s}=$ is defined as the calibration coefficients indicating the impacts of the subsurface residues (acre in $\mathrm{lb}^{-1}$ ),

$B_{u r}=$ is the mass density of live and dead roots found in the upper inch of soil (lb $\operatorname{acre}^{-1} \mathrm{in}^{-1}$,

$B_{u s}=$ is the mass density of incorporated surface residue in the upper inch of soil $\left(\mathrm{lb} \mathrm{acre} \mathrm{en}^{-1}\right)$ and

$c_{u f}=$ is the impact of soil consolidation on the effectiveness of incorporated residue (dimensionless). 
Assumptions made to calculate $P L U$ are:

- $\quad C_{f}$ is accounted for a soil that is not freshly tilled the value taken where a value of 1 is given for a freshly tilled and 0.45 to an undisturbed area over 7 years, the value for this area was 0.5 as the best approximation.

- Based on Yoder et al. (1997), the values for relative effectiveness coefficients on any type of area except frozen areas are:

$$
\begin{aligned}
& C_{b}=0.951, \\
& c_{u r}=0.001999 \text { acre in } \mathrm{lb}^{-1} \\
& c_{u s}=0.000416 \text { acre in } \mathrm{lb}^{-1} \\
& c_{u f}=0.5
\end{aligned}
$$

- $B_{u r}$ was taken from the Table 5.2 in Handbook 703 (Renard et al. 1997), these values were for corn=1060 $\mathrm{lb}$ /acre and for forest=7000 lb /acre, However, since values for forest are not shown in the table, the most similar vegetation to the forest cover was used: fescue tall.

- $\quad B_{u s}$ tended to be 0 because there was no residue incorporated into the plots.

Canopy cover sub-factor, $C C$ reduces the energy of the rainfall on the soil surface, it ranges from 0 to 1 and it is related to $F_{c}$ that is the fraction of land surface covered by canopy and $\mathrm{H}$ given in feet, it represents the distance that raindrops fall after striking the canopy. The equation for $C C$ is shown below:

$$
C C=1-f_{C} * e^{(-0.1 * H)}
$$

Assumptions made to calculate $C C$ are:

- $f_{c}$ has a range from 0 to 1 according to crop type 
- $H$ is taken as the long term with a value of 3 inches.

Both values are shown in Table 5.2 in Handbook 703 (Renard et al. 1997).

The surface cover sub-factor $S C$ is important in determining soil loss ratio because it reduces the capacity of runoff transport and decreases the susceptibility of surface area to raindrop impact. It is related to an empirical coefficient $b$, also to $S_{p}$ as the percentage of the land area covered for it and the surface roughness $R_{u}$.

The surface cover is given by:

$$
S C=e^{\left[-b * S_{p} *\left(\frac{0.24}{R_{u}}\right)^{0.08}\right]}
$$

Assumptions made to calculate $S C$ are:

- The value for $b$ coefficient in a typical cropland erosion conditions is equal to 0.035 .

- $R_{u}$ is the surface roughness taken from Table 5.5 for cropland and Table 5.6 for rangeland conditions in Handbook 703 (Renard et al. 1997) and selected ranges from 0.3 as the best case to 1.9 as the worst case.

- $S_{p}$ is given by the percentage of the residue cover $\left(\right.$ acre* $\left.\mathrm{lb}^{-1}\right)$. It is calculated from the next equation:

$$
S_{p}=\left[1-e\left(-\propto * B_{s}\right)\right] * 100
$$

Where:

$\alpha=$ is the ratio of the area covered by a piece of residue to the mas of that residue $\left(\right.$ acre $\left.1 b^{-1}\right)$ $B_{S}=$ is given as the dry weight of crop residue on the surface $\left(\mathrm{lb} \mathrm{acre}{ }^{-1}\right)$ 
These values were taken from Table 5.1 in Handbook 703 (Renard et al. 1997) selecting a value for $\propto=0.000038$ and a value for $B_{S}=950$, according to the best case.

Yoder et al. (1997) assumed that the capacity on transportation together with runoff detachment is decreased when surface roughness increased. Values for $R_{u}$ were taken from the same source as $R_{u}$ in $S C$. The surface roughness is given by:

$$
S R=e^{\left[-0.66\left(R_{u}-0.24\right)\right]}
$$

The soil moisture sub-factor $S M$ has an important influence on erosion, runoff and infiltration. It shows the soil profile is close to the field capacity, a value of 1 is given as a wet period in response to the equivalent of a continuous fallow plot and a value of 0 that indicates that there is not erosion and runoff that means dry period. Therefore, the relationship among $S M$ and precipitation average monthly was determined and a yearly average of $S M$ was obtained.

\subsubsection{Support practice factor $(P)$}

The support practice factor is the ratio of soil loss with a support practice like countering, strip cropping or terracing to soil loss with straight-row farming up and down the slope. The support practice factor describes terraces, strip cropping and contouring, in some land management applications. In absence of such practices, the $P$ value is equal to 1 (Kouli et al. 2009) )r when data on support practices are not significant ( $\underline{\mathrm{Fu} \text { et al. 2006)}}$. However, there are many scenarios that can show different results because of the management options in soil loss predictions (Angima et al. 2003). In the study area communities, no practices for soil loss were observed seen during the fieldwork; thus, the value for the $P$ factor is 1 .

González-Morales 41 


\section{Chapter IV. Part 2.-METHODOLOGY: SURVEY OF COMMUNITY MEMBERS}

The survey of residents in rural communities near Motozintla de Mendoza was carried out during the spring of 2012, specifically in the months of January to March. The goal of the survey was to gather information about: (a) what the residents know about soil erosion: (b) practices affecting the amount of erosion taking place; and (c) the degree to which residents perceive soil erosion to be a problem.

\subsection{Survey permission}

Before conducting the surveys it was necessary to seek permissions from local officials. For this study, Doctor Neptali Ramirez Marcial, a researcher from ECOSUR as well as a collaborator for the Management and Sustainable Strategies for Regional Development in Grijalva Basin, wrote a letter, introducing me as a Master's Degree student in an Environmental Engineering program collaborating with ECOSUR in the Grijalva watershed project. The letter requested permission for me to conduct research in connection with ECOSUR and provided contact information for additional information (See letter in appendix A-1).

Before conducting any interviews, I travelled to each community in January 2012 and asked for permission to start the interviews. The first place that I visited in each community was the municipality agency, which is where a municipal agent's office is located. Municipal agents are elected by the people and approved by the municipal president to act as the closest link between the government and each community in a municipality. This person is the local authority with many responsibilities in the community, one of which is coordinating the flow of information in the community. 
In seeking permission, I encountered unexpected difficulties in Benito Juarez Centro, Barrio Vicente Guerrero, Carrizal Centro, Barrio La Union and Barrio Plan Grande, all of which are in Motozintla de Mendoza municipality. In years past, these communities had problems with a mining company that came into the communities to seek permission to explore for mineral elements in the communities with promises of community development and employment opportunities. However, the company, in addition to seeking signatures for exploration, also took signatures allowing exploitation, which the communities did not realize at that time. As a result, the communities have a distrust of people taking surveys or asking any form of questions about their communities. Fifty years of concessions for exploration and exploitation have been assigned to the municipality from federal and state government, ending in 2058 (Castro 2009).

The community members are aware that mining is associated with a variety of environmental, social, and health problems. For example, they are concerned because they are living in an area with rugged topography that places them of risk for landslides. Therefore, when I first introduced myself, they were concerned that I was a person from the mining companies collecting information from them to help the mining companies. It was a bit difficult to convince them until I explained that I was from a neighboring farming community, and knew about the concerns of rural communities, I also explained the objectives and importance of this study.

My trip to the Poblado Cambil community to seek the consent of the municipal agent to carry out a survey went without any problems. This community is located in a different municipality (Mazapa de Madero) than the others. After discussing the study's objectives with the municipal agent, he gave me the go ahead to carry out the survey. 


\subsection{Survey design}

The survey was designed as a Knowledge, Attitudes and Practices (KAP) survey, with the goal being to gather information about the communities' knowledge of, attitudes toward, and practices affecting soil erosion. The area selected for the application of the surveys had been chosen to overlay with the areas in which soil samples were taken (See figure 1). In all, the goal was to interview $60 \%$ members of the 396 households in the 6 communities. The information about the total number of households was obtained from municipal agents in each community. The surveys were designed for people ages 18 and older, and could be directed toward any member of a household above that age.

The survey designed as a questionnaire made use of knowledge, attitudes and practices (KAP) methodology such as that described by Gumucio (2011).

The survey questionnaire was designed in five sections:

- The first section was about location information such as, name of the community, date of interview, house number and interviewer's name.

- The second section was about demographic data of the interviewee and consisted of 9 short questions (See Table 11).

- The third section contained the questions that assessed the knowledge that interviewees had about soil erosion and consisted of 10 questions, 7 of them openended questions and 3 short questions (no, yes or numbers for the answer).

- The fourth section is the attitudes section of the KAP methodology with 4 questions, 3 opened questions and 1 short question. 
- Finally, the survey finished with only 1 opened question corresponding to practices as obtained in the KAP methodology for each individual in the selected community (See appendix A-2).

The first draft was revised by Dr. Neptali Ramirez Marcial at Ecosur. After addressing his comments it was sent to Michigan Tech University IRB for approval. As part of the IRB process, I had to prepare a consent form that allowed me to introduce myself to the interviewees during the survey time (See appendix A-3). On February 21, 2012 the project number 312633-1 for knowledge, attitudes and practices survey (KAP) on soil erosion was approved.

Before the surveys took place, I did a pilot test with four people in Porvenir municipality, Chiapas about $26 \mathrm{~km}$ (16 miles) from the study area in order to make sure that the questions were understandable. These tests indicated that some questions were a bit complicated to understand, I then changed the way these questions were worded to make them easier for people to understand.

\subsection{Survey procedure}

The survey procedure in the six communities was developed in the manner described below:

- The surveys were carried out in Spanish by a team of five interviewers, myself and four other interviewers and further explanations were done in a non-technical way for the people to understand.

González-Morales 45 
- The group of workers was trained by me, who explained the sampling procedure and the survey management criteria and the correct way to register in the questionnaires.

- The data recollection technique used was face to face using structured KAP survey methodology.

- During the survey time each interviewer explained the objective of the survey and at the same time asked the consent of the interviewee for its application.

- The interviewee then asked the questions as written. If further explanations were needed, they were provided in a non-technical way.

- I evaluated the quality of the interview each day.

- At the completion of the KAP surveys, all the information was collected together for subsequent analysis.

This survey was carried out in the months of January to March 2012.The data collected was recorded and analyzed in Microsoft excel, utilizing methods to analyze the different variables and some of the results are showed in plots. Demographic information was collected such as; gender, ages, level of education, employment, and type of salary and economy incomes. 


\section{Chapter V. RESULTS AND DISCUSSION FOR SOIL EROSION RATES}

The results for erosion rates in the six communities applying RUSLE model are explained in the next sections. Each one of the factors derived from RUSLE was calculated, except $R$ factor that was analyzed from Buenos Aires meteorological station showed in Table 1 and figure 4.

\subsection{Rainfall erosivity ( $R$ factor)}

Figure 6 shows the average monthly rainfall. The rainy season extends from starting from May to October, with September followed by June being the highest rainfall months.

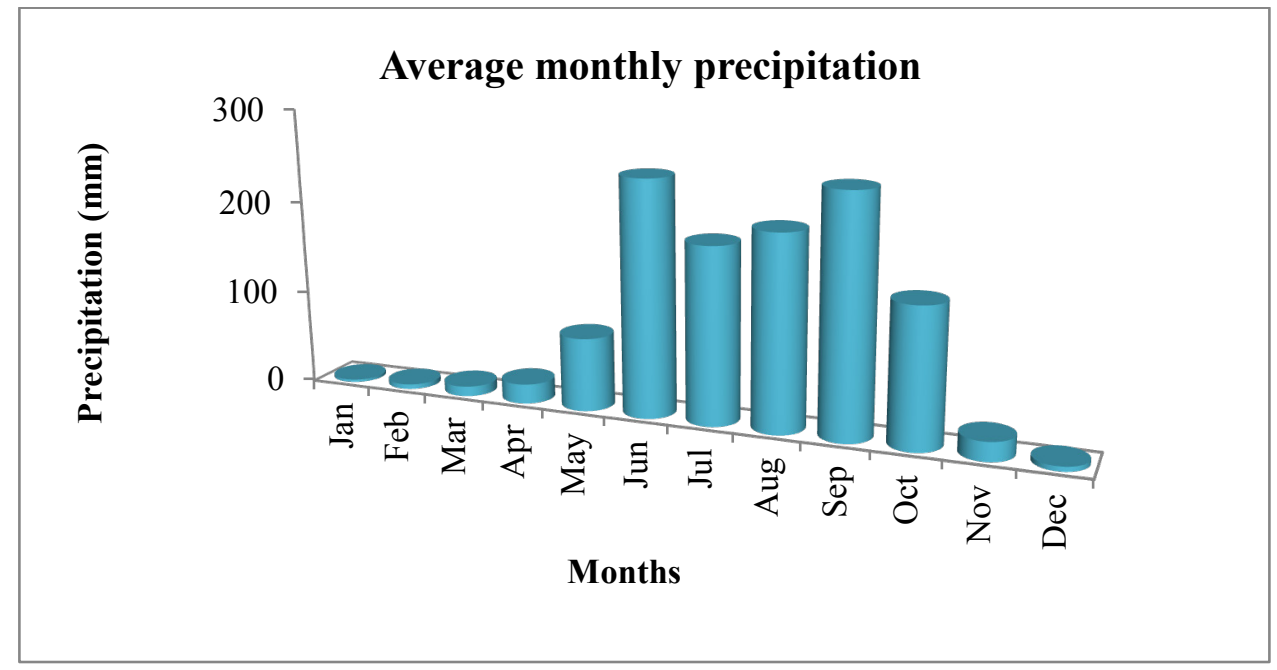

Figure 6: Average monthly precipitation of Buenos Aires Station (1980-2009)

The Fournier Modified Index (see equation (3)) was used to obtain a rainfall erosion index of $197 \mathrm{~mm}$, based on the using the average monthly precipitation values in Figure 6 and an annual average precipitation obtained of $1191 \mathrm{~mm}$. The rainfall erosivity factor was calculated as $17,350 \mathrm{MJ} \mathrm{mm} \mathrm{ha}^{-1} \mathrm{~h}^{-1} \mathrm{yr}^{-1}$ using equation (4). 


\subsection{Soil erodibility ( $K$ factor)}

The values of the $K$ factor obtained for each plot are shown in Table 5, where $K$ ranges from 0.011 to 0.042 ton ha h ha ${ }^{-1} \mathrm{MJ}^{-1} \mathrm{~mm}^{-1}$. According to Renard et al., (1991), $K$ values can range from about 0.10 to 0.45 ton acre ${ }^{-1}$ U.S customary units $(0.01$ to 0.5 ton ha h ha

${ }^{1} \mathrm{MJ}^{-1} \mathrm{~mm}^{-1}$ SI metric units). Renard et al., (1991), explains that plots with high sand and high clay contents have lower $K$ values and plots with high silt content have higher $K$ values.

Table 5: Soil erodibility, $K$ factor values provided in SI metric units

\begin{tabular}{|c|c|c|c|c|c|c|c|}
\hline Community & Plot & $\begin{array}{l}\text { Textural } \\
\text { Name }\end{array}$ & $K$ & Community & Plot & Textural Name & $K$ \\
\hline \multirow{8}{*}{$\begin{array}{l}\text { Benito Juárez } \\
\text { Centro }\end{array}$} & 1 & Loam & 0.024 & \multirow{8}{*}{$\begin{array}{l}\text { Poblado } \\
\text { Cambil }\end{array}$} & 25 & Clay loam & 0.035 \\
\hline & 2 & Loam & 0.024 & & 26 & Loam & 0.032 \\
\hline & 3 & Loam & 0.020 & & 27 & Silt loam & 0.034 \\
\hline & 4 & Loam & 0.021 & & 28 & Loam & 0.042 \\
\hline & 5 & Loam & 0.019 & & 29 & Loam & 0.033 \\
\hline & 6 & Loam & 0.016 & & 30 & Loam & 0.033 \\
\hline & 7 & Silt loam & 0.017 & & 31 & Sandy loam & 0.023 \\
\hline & 8 & Silt loam & 0.020 & & 32 & Loam & 0.014 \\
\hline \multirow{8}{*}{$\begin{array}{l}\text { Barrio Vicente } \\
\text { Guerrero }\end{array}$} & 9 & Loam & 0.023 & \multirow{8}{*}{$\begin{array}{l}\text { Barrio Plan } \\
\text { Grande }\end{array}$} & 33 & Sandy loam & 0.024 \\
\hline & 10 & Loam & 0.023 & & 34 & Sandy loam & 0.023 \\
\hline & 11 & Loam & 0.026 & & 35 & Sandy loam & 0.021 \\
\hline & 12 & Sandy loam & 0.026 & & 36 & Silt loam & 0.027 \\
\hline & 13 & Sandy loam & 0.013 & & 37 & Loam & 0.028 \\
\hline & 14 & Sandy loam & 0.014 & & 38 & Silt loam & 0.026 \\
\hline & 15 & Loam & 0.021 & & 39 & Loam & 0.034 \\
\hline & 16 & Sandy loam & 0.023 & & 40 & Silt loam & 0.035 \\
\hline \multirow{8}{*}{$\begin{array}{l}\text { Carrizal } \\
\text { Centro }\end{array}$} & 17 & Sandy loam & 0.012 & \multirow{8}{*}{$\begin{array}{l}\text { Barrio } \\
\text { Union }\end{array}$} & 41 & Silty clay & 0.031 \\
\hline & 18 & Loam & 0.016 & & 42 & Clay loam & 0.019 \\
\hline & 19 & Loam & 0.017 & & 43 & Silty Clay loam & 0.013 \\
\hline & 20 & Sandy loam & 0.011 & & 44 & Clayey & 0.026 \\
\hline & 21 & Loam & 0.018 & & 45 & Clay loam & 0.017 \\
\hline & 22 & Loam & 0.027 & & 46 & Clay loam & 0.019 \\
\hline & 23 & Loam & 0.016 & & 47 & Clay loam & 0.020 \\
\hline & 24 & Loam & 0.026 & & 48 & Clay loam & 0.019 \\
\hline
\end{tabular}

It can be seen that, Poblado Cambil, Barrio Plan Grande and Barrio La Union have soils most vulnerable to erosion. 
In these communities, the obtained $K$ values could have changed by effects of land use such as it can be seen in Table 7, the use of the lands were corn crops, low percentage in forest coverage (See Table 8) and grazing lands.

\subsection{Length slope and slope steepness factors}

As Table 6 shows, the $L S$ factors are high compared to typical values in the Table 4.1 in Agriculture Handbook 703 (see Renard et al., 1997).

Table 6: Topographic values for $L$ and $S$ factors

\begin{tabular}{|c|c|c|c|c|c|}
\hline Community & Plot & $L S$ & Community & Plot & $L S$ \\
\hline \multirow{8}{*}{ Benito Juárez Centro } & 1 & 86 & \multirow{8}{*}{ Poblado Cambil } & 25 & 105 \\
\hline & 2 & 53 & & 26 & 90 \\
\hline & 3 & 103 & & 27 & 68 \\
\hline & 4 & 165 & & 28 & 43 \\
\hline & 5 & 139 & & 29 & 97 \\
\hline & 6 & 135 & & 30 & 82 \\
\hline & 7 & 96 & & 31 & 70 \\
\hline & 8 & 62 & & 32 & 104 \\
\hline \multirow{8}{*}{$\begin{array}{l}\text { Barrio } \\
\text { Guerrero }\end{array}$} & 9 & 118 & \multirow{8}{*}{$\begin{array}{l}\text { Barrio } \\
\text { Grande }\end{array}$} & 33 & 51 \\
\hline & 10 & 80 & & 34 & 67 \\
\hline & 11 & 57 & & 35 & 67 \\
\hline & 12 & 59 & & 36 & 15 \\
\hline & 13 & 70 & & 37 & 51 \\
\hline & 14 & 89 & & 38 & 45 \\
\hline & 15 & 135 & & 39 & 18 \\
\hline & 16 & 187 & & 40 & 24 \\
\hline \multirow{8}{*}{ Carrizal Centro } & 17 & 74 & \multirow{8}{*}{ Barrio La Union } & 41 & 164 \\
\hline & 18 & 50 & & 42 & 52 \\
\hline & 19 & 49 & & 43 & 89 \\
\hline & 20 & 85 & & 44 & 29 \\
\hline & 21 & 90 & & 45 & 106 \\
\hline & 22 & 47 & & 46 & 73 \\
\hline & 23 & 200 & & 47 & 77 \\
\hline & 24 & 63 & & 48 & 114 \\
\hline
\end{tabular}


These high values are because many of the slopes in the 48 plots were very high (many are greater than $60^{\circ}$ ); at the same time, most of the slope lengths also were high; however. Renard et al. (1997) explains that erosion rates are more sensitive to higher slopes than changes in slope length. Overall, these steep and long hill slopes will lead to large erosion rates.

Table 6 shows these areas with high topography Benito Juarez Centro, Barrio Vicente Guerrero, Barrio La Union, Poblado Cambil, Carrizal Centro and Barrio Plan Grande and the values of $L S$ values obtained for plots in these areas. From Table 6 it can be seen that Benito Juarez Centro has more plots with relatively high values of LS followed by Barrio Vicente Guerrero and then Barrio La Union, Poblado Cambil, Carrizal Centro and lastly Barrio Plan Grande in a decreasing order of number of plots with high $L S$ values. It should however be noted that the highest $L S$ value of about 200 was obtained in Carrizal Centro while the lowest of about 15 was found in Barrio Plan Grande.

\subsection{Cover vegetation ( $C$ factor)}

As can be seen in Table 7, $C$ factor values have ranges from 0.03 to 0.06 ; according to Renard (1991) values for $C$ can vary from 0 to 1.5 , where 0 is applied for a very well protected soil and 1.5 for a very disturbed soil.Most of the cover vegetation in the study area was forests with different percentages on coverage (see appendix cd). The plots selected in the study area are not under tillage system, the differences between communities are similar each other. However, values estimated with low percentage on vegetation cover and high precipitation contributes to greater splash for raindrops.

González-Morales 50 
Table 7: Cover management $C$ factor

\begin{tabular}{|c|c|c|c|c|c|c|c|}
\hline Community & Plot & Cover & C & Community & Plot & Cover & $C$ \\
\hline \multirow{8}{*}{$\begin{array}{l}\text { Benito Juárez } \\
\text { Centro }\end{array}$} & 1 & Forest & 0.02 & \multirow{8}{*}{$\begin{array}{l}\text { Poblado } \\
\text { Cambil }\end{array}$} & 25 & Forest & 0.03 \\
\hline & 2 & Forest & 0.03 & & 26 & Forest & 0.03 \\
\hline & 3 & Forest & 0.03 & & 27 & Forest & 0.03 \\
\hline & 4 & Forest & 0.02 & & 28 & Forest & 0.03 \\
\hline & 5 & Scholar plot & 0.02 & & 29 & Forest & 0.03 \\
\hline & 6 & Forest & 0.02 & & 30 & Forest & 0.03 \\
\hline & 7 & Forest & 0.02 & & 31 & Forest & 0.03 \\
\hline & 8 & Forest & 0.02 & & 32 & Forest & 0.03 \\
\hline \multirow{8}{*}{$\begin{array}{l}\text { Barrio Vicente } \\
\text { Guerrero }\end{array}$} & 9 & Corn & 0.02 & \multirow{8}{*}{$\begin{array}{l}\text { Barrio Plan } \\
\text { Grande }\end{array}$} & 33 & Reforested & 0.03 \\
\hline & 10 & Forest & 0.03 & & 34 & Reforested & 0.03 \\
\hline & 11 & Forest & 0.03 & & 35 & Forest & 0.03 \\
\hline & 12 & Forest & 0.03 & & 36 & Corn & 0.02 \\
\hline & 13 & Forest & 0.03 & & 37 & Corn & 0.01 \\
\hline & 14 & Forest & 0.02 & & 38 & Forest & 0.03 \\
\hline & 15 & Forest & 0.03 & & 39 & Pasture & 0.02 \\
\hline & 16 & Forest & 0.03 & & 40 & Forest & 0.03 \\
\hline \multirow{8}{*}{ Carrizal Centro } & 17 & Forest & 0.03 & \multirow{8}{*}{$\begin{array}{l}\text { Barrio } \quad \text { La } \\
\text { Union }\end{array}$} & 41 & Pasture & 0.05 \\
\hline & 18 & Forest & 0.02 & & 42 & Corn & 0.03 \\
\hline & 19 & Forest & 0.02 & & 43 & Forest & 0.05 \\
\hline & 20 & Forest & 0.03 & & 44 & Corn & 0.03 \\
\hline & 21 & Forest & 0.03 & & 45 & Corn & 0.03 \\
\hline & 22 & Forest & 0.03 & & 46 & Corn & 0.04 \\
\hline & 23 & Forest & 0.03 & & 47 & Corn & 0.04 \\
\hline & 24 & Forest & 0.03 & & 48 & Pasture & 0.06 \\
\hline
\end{tabular}

\subsection{Conservation practice ( $P$ factor)}

For $P$ factor, there are no conservation practices in any of the 48 plots analyzed into the six communities. Conservation practices refers to mechanical introduction or maintenance of support practices; according to the literature review, when there is not significance or the lack of the conservation practices does exist the value of the $P$ factor is equal to 1 (Kouli et al. 2009). However, some studies researches have shown that soil erosion could decrease if the land has an appropriate management (Maeda et al. 2010). 


\subsection{Annual average of soil erosion rates $(A)$}

At the end of the six RUSLE factors calculations, the annual soil erosion rates $(A)$ expressed in ton $\mathrm{ha}^{-1} \mathrm{yr}^{-1}$ were obtained per each plot in the six communities is shown in Table 8.

Table 8: Annual average of soil erosion rates $\boldsymbol{A}$

\begin{tabular}{|c|c|c|c|c|c|c|c|c|c|}
\hline Community & Plot & Cover & \% Cover & $A$ & Community & Plot & Cover & \%Cover & $A$ \\
\hline \multirow{8}{*}{$\begin{array}{l}\text { Benito } \\
\text { Juárez } \\
\text { Centro }\end{array}$} & 1 & Forest & 100 & 590 & \multirow{8}{*}{$\begin{array}{l}\text { Poblado } \\
\text { Cambil }\end{array}$} & 25 & Forest & 40 & 1,700 \\
\hline & 2 & Forest & 30 & 660 & & 26 & Forest & 20 & 1,400 \\
\hline & 3 & Forest & 40 & 980 & & 27 & Forest & 40 & 1,100 \\
\hline & 4 & Forest & 80 & 1,300 & & 28 & Forest & 40 & 850 \\
\hline & 5 & $\begin{array}{l}\text { Scholar } \\
\text { Plot }\end{array}$ & 10 & 1,100 & & 29 & Forest & 30 & 1,700 \\
\hline & 6 & Forest & 90 & 790 & & 30 & Forest & 40 & 1,300 \\
\hline & 7 & Forest & 80 & 640 & & 31 & Forest & 30 & 860 \\
\hline & 8 & Forest & 80 & 490 & & 32 & Forest & 40 & 690 \\
\hline \multirow{8}{*}{$\begin{array}{l}\text { Barrio } \\
\text { Vicente } \\
\text { Guerrero }\end{array}$} & 9 & Corn & 100 & 770 & \multirow{8}{*}{$\begin{array}{l}\text { Barrio Plan } \\
\text { Grande }\end{array}$} & 33 & Refor. & 20 & 600 \\
\hline & 10 & Forest & 20 & 900 & & 34 & Refor. & 20 & 740 \\
\hline & 11 & Forest & 70 & 700 & & 35 & Forest & 20 & 700 \\
\hline & 12 & Forest & 50 & 770 & & 36 & Corn & 100 & 100 \\
\hline & 13 & Forest & 60 & 400 & & 37 & Corn & 100 & 320 \\
\hline & 14 & Forest & 5 & 530 & & 38 & Forest & 20 & 570 \\
\hline & 15 & Forest & 50 & 1,500 & & 39 & Pasture & 10 & 260 \\
\hline & 16 & Forest & 60 & 1,900 & & 40 & Forest & 20 & 400 \\
\hline \multirow{8}{*}{$\begin{array}{l}\text { Carrizal } \\
\text { Centro }\end{array}$} & 17 & Forest & 40 & 400 & \multirow{8}{*}{$\begin{array}{l}\text { Barrio La } \\
\text { Union }\end{array}$} & 41 & Pasture & 10 & 2,050 \\
\hline & 18 & Forest & 80 & 320 & & 42 & Corn & 100 & 290 \\
\hline & 19 & Forest & 80 & 300 & & 43 & Forest & 10 & 500 \\
\hline & 20 & Forest & 40 & 450 & & 44 & Corn & 100 & 200 \\
\hline & 21 & Forest & 40 & 770 & & 45 & Corn & 100 & 530 \\
\hline & 22 & Forest & 30 & 670 & & 46 & Corn & 100 & 400 \\
\hline & 23 & Forest & 20 & 1,590 & & 47 & Corn & 100 & 450 \\
\hline & 24 & Forest & 40 & 770 & & 48 & Pasture & 10 & 900 \\
\hline
\end{tabular}

As can be seen, Poblado Cambil has areas with more vulnerability to soil erosion problems, followed by Barrio Vicente Guerrero where two of its plots present a high annual average soil loss rate. The next community that enfaces this problem is Barrio $\mathrm{La}$ 
Union that shows only one higher value almost with the same amount of areas with vulnerability to soil erosion comparing with Carrizal Centro and Benito Juarez Centro ending up with Plan Grande with less vulnerability to soil erosion than the others.

Annual average soil erosion rates depended from different values obtained from the six factors. The rainfall factor was the same value used along the plots and the soil erodibility factor results from analysis were similar among the plots. Although most of the cover vegetation was forest (Astilleros) percentages of cover differed significantly between the plots, as did the topographic factors.

From a study taken place in Chiapas in conditions without conservation practices values from 13,100, 565, 3400 until 20,000 ton $\mathrm{ha}^{-1} \mathrm{yr}^{-1}$ were obtained (Santacruz-DeLeon 2011). The areas analyzed were forested. The high values were explained by high slopes and surfaces with temporal agriculture (Santacruz-DeLeon 2011). These ranges are similar with the ranges obtained in this study.

Annual average of soil loss from the Table 8 may be explained that some of the high values as shown in plot 4 with $80 \%$ of forest and 1,300 ton $\mathrm{ha}^{-1} \mathrm{yr}^{-1}$ may be affected by high slopes length and high slope steepness; McCool et al. (1987) explain that the soil loss increases faster due to high topographies. In addition to that, with only trees in an area is still exposed to soil loss because the force of raindrop is still strong from a tree to the ground with no medium or lower cover vegetation.

Also in results showed above the plots used for corn crops, it can be seen that soil erosion decreases as is the case of 36 plot located in Barrio Plan Grande, as the land use is covered for most part of the year, the period of cropping is from May to January in those 
areas and the slopes are not too high. Also, in these areas the lands are not tilled for cropping such as corn and beans.

Table 9 gives the annual average and standard deviation of soil loss rates for each community. The results in Table 9 illustrate that Barrio La Union shows a widest range of vulnerability to soil erosion comparing with the other communities.

Table 9: Mean and standard deviation in comparison between communities

\begin{tabular}{lcc}
\hline Community & Mean & Standard Deviation \\
\hline Benito Juarez Centro & 820 & 290 \\
B. Vicente Guerrero & 930 & 500 \\
Carrizal Centro & 660 & 420 \\
Poblado Cambil & 1,200 & 390 \\
B. Plan Grande & 460 & 220 \\
B. La Union & 660 & 600 \\
\hline
\end{tabular}

\subsection{Limitations of soil erosion rate calculations}

The limitations of the model calculations include the following.

- $\quad R$ factor-The data needed for its calculation was poor due to lack of gauges with 30 min intensity measurements.

- $K$ factor- The $\%$ of modified silt was not found for $M$ calculations, and it was assumed to be closer to $\%$ of silt

- In $C$ factor- This factor was limited in several data: Most of the data were taken in plots with forest as land cover vegetation and RUSLE model has databases does not have databases for forest. So, the values taken in this study were assumed to the closer value to forest. In addition, for getting the necessary information for $C$ factor calculation has to be established specific plots for a long time ago in order 
to observe and analyze more exactly the measurements. Some of the specific limitations and assumptions for the $C$ factors are as follows.

- Prior Land Use $(P L U)$ because the values given 1 for freshly tilled and 0.45 when the land has left undisturbed over than 7 years. My study area has had forest cover for many years ago. The value assumed was 0.5 .

- Bur was not measured in the field so the values taken were from tables given by Agriculture Handbook 703. There was not data for forest vegetation, it was taken the closer value found in the table 5.2.

○ Bus was assumed to be equal to 0, because any residue was incorporated into the plots. Forest does not allow the incorporation of residues mechanically. The values for Bus are for crops or grazing.

- In Canopy cover (CC) uses $f c$ and $H$ are also analyzed and showed in tables, however there is not information for forest. It was taken the value closer or assumed similar to forest. 


\section{Chapter VI. RESULTS AND DISCUSSION FOR SOCIAL SURVEYS}

The interviews were completed over the course of 15 days and involved a total of 236 households. Table 10 shows a breakdown of the total number of households in each community as well as the number of households interviewed in each community. In all about $60 \%$ of all households in these communities were interviewed, resulting in the data in this survey being representative for the entire community.

Table 10: Total households per community and total interviewed

\begin{tabular}{lccc}
\hline Community & Total Households & Household interviewed & $\mathbf{( \% )}$ \\
\hline Benito Juarez Centro & 125 & 72 & 58 \\
Carrizal Centro & 120 & 70 & 58 \\
Barrio Vicente Guerrero & 60 & 37 & 62 \\
Barrio Plan Grande & 40 & 24 & 60 \\
Barrio La Union & 21 & 15 & 71 \\
Poblado Cambil & 30 & 18 & 60 \\
& $\mathbf{3 9 6}$ & $\mathbf{2 3 6}$ & $\mathbf{6 0}$ \\
\hline
\end{tabular}

\subsection{Demographic summary}

Table 11 summarizes the demographic information of the people who were interviewed. In total, 52\% (123 households) of the people interviewed were females, most of whom were housewives.

In terms of education $34 \%$ (80 households) of the people interviewed had at least elementary school level education but only $1 \%$ finished high school ( 2 households). About 46\% (108 households) of those interviewed work on their own land. About $61 \%$ of the population interviewed had incomes less than or equal to $\$ 1,000$ Mexican pesos of those incomes, 36\% (85 households) were from Government support program called 'Oportunidades' (Table 11). 
Table 11: Demographic information of interviewees

\begin{tabular}{|c|c|c|}
\hline Gender & Count & Percentage \\
\hline Female & 123 & $52 \%$ \\
\hline Male & 113 & $48 \%$ \\
\hline Ages (18-89) & Count & Percentage \\
\hline $18-30$ & 57 & $24 \%$ \\
\hline $31-40$ & 58 & $25 \%$ \\
\hline $41-55$ & 66 & $28 \%$ \\
\hline over 56 & 55 & $23 \%$ \\
\hline Education level & Count & Percentage \\
\hline Illiterate & 9 & $4 \%$ \\
\hline Drop out elementary in $1^{\text {st }}$ grade & 10 & $4 \%$ \\
\hline Drop out elementary in $2^{\text {nd }}$ grade & 32 & $14 \%$ \\
\hline Drop out elementary in $3^{\text {rd }}$ grade & 32 & $14 \%$ \\
\hline Drop out elementary in $4^{\text {th }}$ grade & 29 & $12 \%$ \\
\hline Drop out elementary in $5^{\text {th }}$ grade & 12 & $5 \%$ \\
\hline Finished Elementary school & 80 & $34 \%$ \\
\hline Drop out Middle school & 4 & $2 \%$ \\
\hline Finished Middle school & 24 & $10 \%$ \\
\hline Currently high School & 1 & $<1 \%$ \\
\hline Drop out High school & 1 & $<1 \%$ \\
\hline Finished High school & 2 & $1 \%$ \\
\hline Employment & Count & Percentage \\
\hline City (various) & 6 & $3 \%$ \\
\hline Clerical & 1 & $<1 \%$ \\
\hline Housewives & 115 & $49 \%$ \\
\hline Inside of the community (Various) & 5 & $2 \%$ \\
\hline Own lands & 108 & $46 \%$ \\
\hline Student & 1 & $<1 \%$ \\
\hline Incomes (monthly average) & Count & Percentages \\
\hline Equal or less than 2500 & 2 & $1 \%$ \\
\hline Equal or less than 1000 & 143 & $61 \%$ \\
\hline Equal to 1500 & 2 & $1 \%$ \\
\hline No incomes & 89 & $38 \%$ \\
\hline Type of incomes & Count & Percentage \\
\hline Government support, AMANECER AND 70 Y MAS & 3 & $1 \%$ \\
\hline Government support, AMANECER & 4 & $2 \%$ \\
\hline Government support, OPORTUNIDADES & 85 & $36 \%$ \\
\hline Government support, 70 Y MAS & 2 & $1 \%$ \\
\hline Government support, PROCAMPO & 44 & $19 \%$ \\
\hline Government support, AMANECER and PROCAMPO & 2 & $1 \%$ \\
\hline Government support, PROCAMPO and OPORTUNIDADES & 2 & $1 \%$ \\
\hline Others & 5 & $2 \%$ \\
\hline No salary & 89 & $38 \%$ \\
\hline
\end{tabular}


Government programs are an important source of income in these communities. These programs are: Oportunidades, as mentioned before, is a federal program provided by Secretaria de Desarrollo Social (SEDESOL) to benefit housewives and children in the area of health, education and nutrition. Another federal program called Programas de Apoyo directos al Campo (PROCAMPO) managed by Secretaria de Agricultura, Ganaderia, Desarrollo rural, Pesca y Alimentacion (SAGARPA) provided incomes to about $19 \%$ (44 households) of those surveyed (Table 11).

70 y MAS is also a federal program by SEDESOL benefiting elders with ages equal or greater than 70 and covering health and nutrition. The AMANECER program support provided by Chiapas State covers health and nutrition and benefits elders with ages equal or greater than 64 .

\subsection{Knowledge of soil erosion}

The knowledge section of the survey was aimed at determining the interviewee's understanding of what soil erosion is, their perspective on the causes of erosion, and how the land under study can be conserved either through preventive measures or control measures. To achieve this, the knowledge section was divided into 10 questions. The complete questionnaire can be found in appendix A-2.

First, the participants were asked whether they knew what soil erosion was; the question was specifically written as:

"Do you know what soil erosion is?" 
The responses show that $69 \%$ of those interviewed did not know what soil erosion was. When analyzed based on gender, the data show that a higher percentage of the males indicated that they knew what soil erosion was, as shown in Table 12.

Table 12: Knowledge of what soil erosion is by gender

\begin{tabular}{lccc}
\hline \multicolumn{2}{c}{ Soil Erosion } & \multicolumn{2}{c}{ Percentage (\%) } \\
Gender & Count & Yes & Not \\
\hline Female & 123 & 19 & 81 \\
Male & 113 & 43 & 57 \\
\hline
\end{tabular}

The data also shows a difference by community. From Table 13, it can be observed that the Barrio Plan Grande community has a larger percentage of its household having knowledge of what soil erosion is, all other communities have a larger percentage of its households not having the knowledge of what soil erosion is such as Barrio La Union.

Table 13: Level of knowledge per community

\begin{tabular}{lccc}
\hline & \multicolumn{3}{c}{ Percentage (\%) } \\
Community & Household & Yes & No \\
\hline Benito Juarez Centro & 72 & 32 & 68 \\
Carrizal Centro & 70 & 23 & 77 \\
BarrioVicente Guerrero & 37 & 19 & 81 \\
Barrio Plan Grande & 24 & 63 & 38 \\
Barrio La Union & 15 & 20 & 80 \\
Poblado Cambil & 18 & 44 & 56 \\
Total household & $\mathbf{2 3 6}$ & $\mathbf{3 1}$ & $\mathbf{6 9}$ \\
\hline
\end{tabular}

A second question that asked was if the interviewees knew the location of any area affected by soil erosion. This question was asked after soil erosion and its causes had been explained in a non-technical manner. 
The specific question was:

"Do you know what the most eroded area of the community is?"

One of the important things that the responses revealed was that many knew what erosion was, even if they were not familiar with the word itself. When the question about the soil erosion knowledge was applied most of them said, "No I do not know". However, after the brief explanation about what is a soil erosion most of them said "Oh, it is about that, I know about a lot of landslides close to my neighbor house" or "the soil has been losing in my own land" or "Close to the church a landslide occurred" or "Behind to the school".

So, it can be deduced that although many interviewees were not familiar the term 'soil erosion', they knew of the effects of soil erosion and also areas affected by soil erosion. Hence, there is a jump in the percentages from Table 12 (where the term soil erosion was merely asked without further explanation) to Table 14 which reflects the knowledge that interviews had about soil erosion. Significantly, the percentages of females with knowledge about erosion jumped from $19 \%$ to $91 \%$ after the causes and effects of soil erosion were explained in a non-technical way and they were given a chance to identify locations where erosion was happening.

Table 14: Knowledge on the most eroded area of the community.

\begin{tabular}{lccc}
\hline Knowledge about the eroded area of the community & \multicolumn{3}{c}{ Percentages (\%) } \\
Gender & Count & Yes & Not \\
\hline Female & 123 & 91 & 9 \\
Male & 113 & 95 & 5 \\
\hline
\end{tabular}

A third question was asked about what interviewees thought caused the soil erosion in the affected areas. As shown in Figure 7, the largest percentage of population (more than 
$40 \%$ ) perceived that the major cause of soil erosion in the affected areas was hurricanes (stronger rainfall), followed by rainfall (normal period of rain) of about $30 \%$. Only about $2 \%$ of the total population said that agriculture and livestock was a major cause of erosion. However, agriculture and livestock not only is a significant cause of soil erosion but also can make land more vulnerability to heavy rainfall (Rodríguez S et al. 2000).

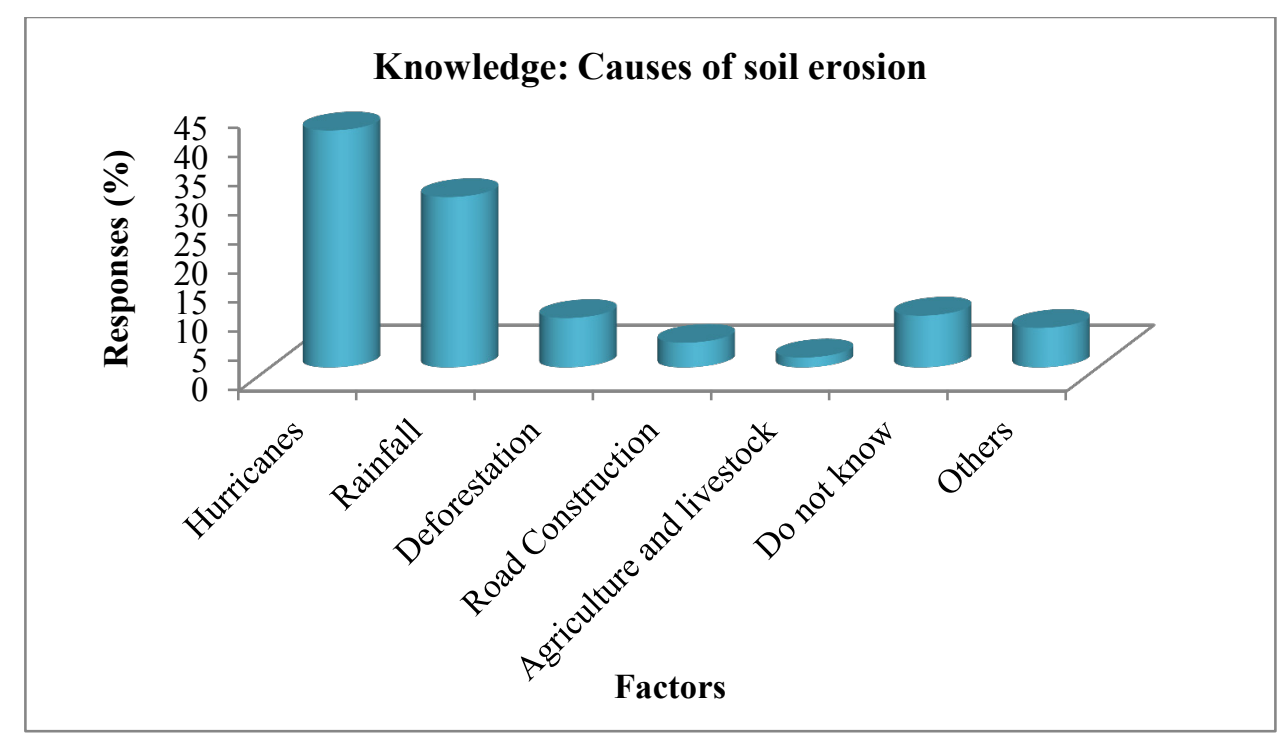

Figure 7: Perceived factors causing soil erosion by the people

Figure 8 shows the responses to a question about whether those who knew where the eroded areas were located also knew about the land use in the specific eroded areas. The highest response, $36 \%$, was that the land was used for human settlements, while about $28 \%$ responded that the land was used for farm lands with corn crops and $14 \%$ said that those areas are used for Astilleros (common land) where they took firewood. 


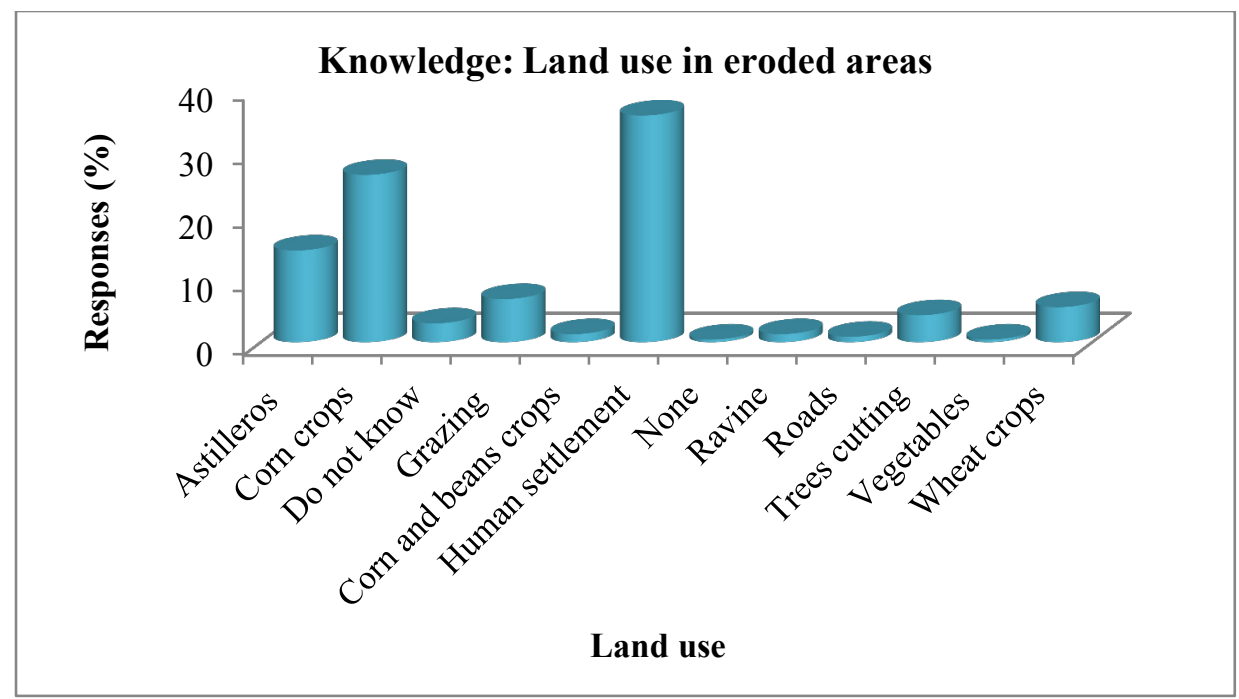

Figure 8: Reported land use in eroded areas by the people

That most believe the most eroded areas are in areas of human settlement rather than farm land helps to explain why they do see agricultural practices to be an important cause of erosion. Human settlements occur has a big effect because they have to cut trees and clean the area for their construction and for crop lands where they get their food. Followed of the slopes in those areas, high precipitation and the land without cover help the erosion to increase.

The interviewees were also asked if they know about the consequences of soil erosion. In Figure 9 we see that landslides is the consequence perceived by the most interviewees (20\%) as being significant. $13 \%$ identify mudslides as an important consequence and about $11 \%$ said that soil erosion causes human death in extreme cases. However, about $28 \%$ said that they do not know about the consequences. 


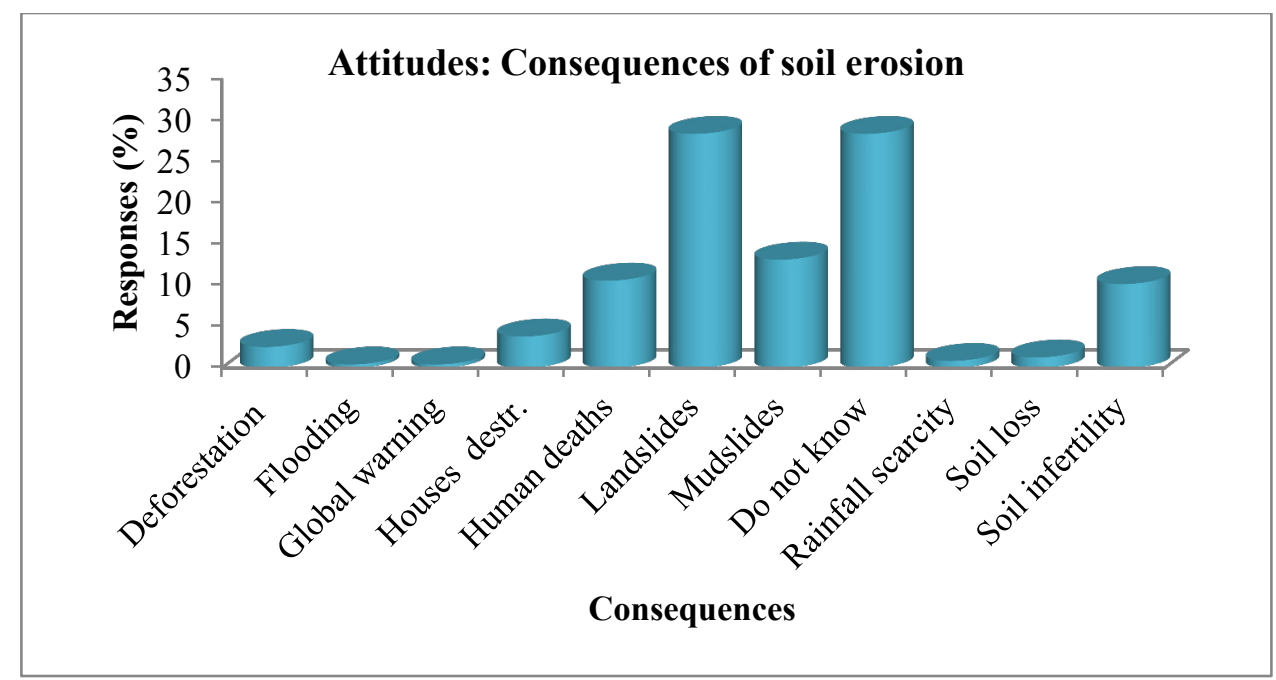

Figure 9: Perceived consequences by the people

Interviewees were also asked where they obtained knowledge about soil erosion. As we can see, the biggest source (with about 62\%) is from personal experience followed by experiences from family members (about 15\%). Only 5\% indicated that they obtained their knowledge from government programs and $6 \%$ they simply said that they did not know.

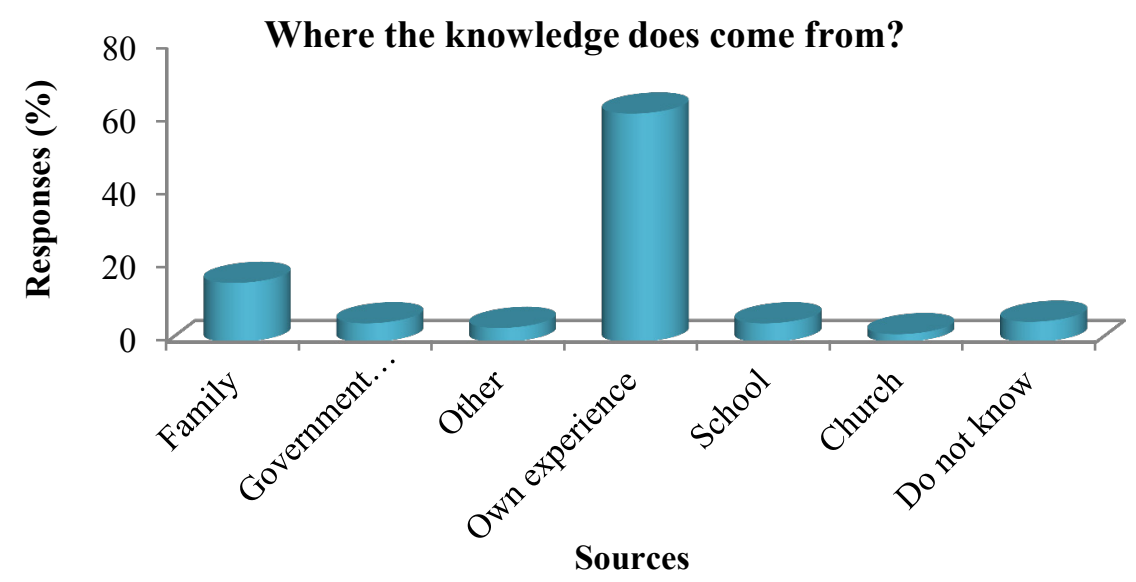

Figure 10: Sources where knowledge has been obtained

González-Morales 63 
The issue with having the knowledge of soil erosion from personal experience may suggest a reactive measure is usually taken to conserve the land after erosion has occurred instead of a cautionary approach of proper land use to limit the effect of soil erosion.

\subsection{Attitudes}

In this section, we asked about who should take the responsibility to solve the erosion problems.

The specific question was:

"Who do you think should solve the problem of erosion?"

As we can see in Figure 11, about $42 \%$ believe it to be the responsibility of the government, while about $26 \%$ said it was the responsibility of the community. However, $17 \%$ said that the responsibilities should be shared by the community and government.

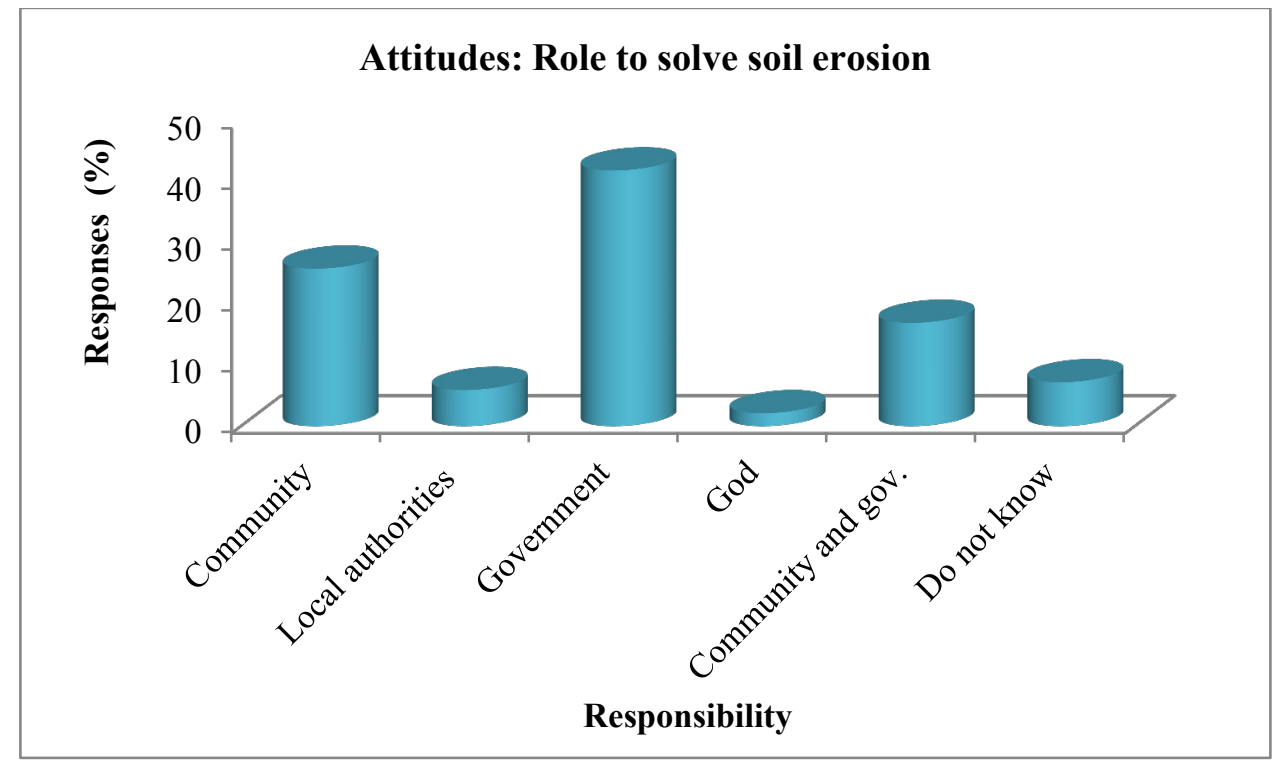

Figure 11: Responsibility to solve soil erosion 
Figure 12 shows the people's attitudes about what they are willing to do to reduce the soil erosion. A bit more than $50 \%$ said that could help with reforestation being a practical option to reduce soil erosion, $16 \%$ responded that reforestation together with terracing could help the problem, $9 \%$ of them did not know about the way to help to reduce soil erosion, while $3 \%$ said that the government has to help them with programs.

However, even though the people know about reforestation as a soil conservation practice, a phrase caught my attention when an interviewee said "if the government pays me for reforestation, I will do it", as a result, it seemed to me that some people were more concerned about personal gains from combating soil erosion than the environmental benefits.

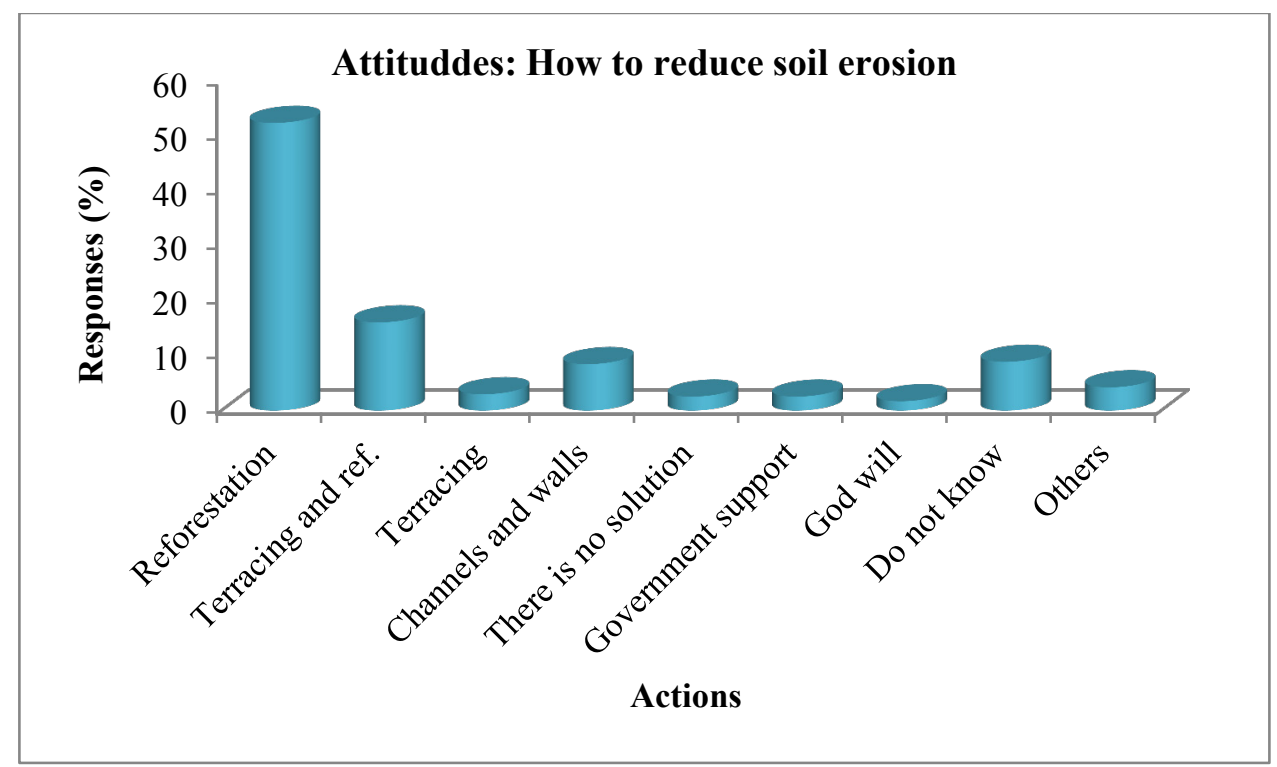

Figure 12: Actions to reduce soil erosion

\subsection{Practices}

The last question involved what practices the people were currently employing to conserve their land. Most of the people believe that reforestation is the practice to be 
used. As can be seen from Figure 14, more than $37 \%$ said they carried out reforestation practices to conserve their land while about $36 \%$ of the population does nothing.

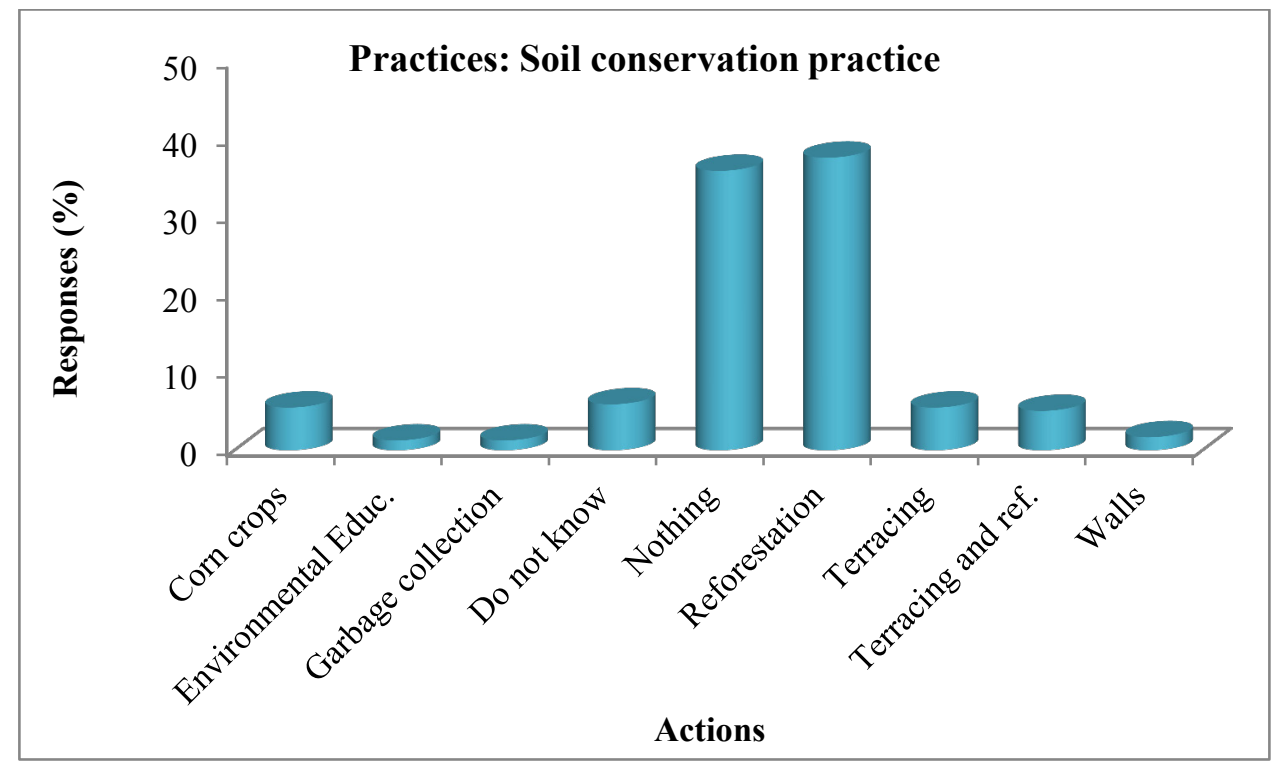

Figure 13: Practices for soil conservation

It is important to see that restoration is one of the biggest soil conservation practices carried out in the communities.

This practice is, however, limited by a couple of issues. Firstly, when they need trees, they are required to fill a document requesting those trees. Then, they are supplied with trees pines and cypress instead of tress such as oak which the people think is more effective for reforestation practices. Another reason behind the supply of pines and cypress may also be due to the fact the communities also prefer oak trees to the supplied trees for firewood for cooking.

Secondly, the numbers of trees that arrive at the Ejido yearly are usually not enough to properly combat soil erosion in areas affected or areas prone to soil erosion. 
From the people experience the reforestation is very important, however some of them are not concerned about the soil erosion problem, such as during one of the talks a person said, "For us the forest are very important because we need it for to obtain wood and then to use them for houses construction or for furniture materials, or also for wood selling, that's why the forest is almost ending, because we have good trees for wood and we can get money", while another issue presented is that people in those communities do not own big areas of lands, a person said "If I reforest my land, where I'm going to plant my maize, what I'm going to eat, or what I will give to my kids for their food", there is not option for them. 


\section{Chapter VII. CONCLUSIONS}

One of the purposes of this report was to assess soil erosion vulnerability in six communities in the vicinity of Motozintla de Mendoza, Chiapas, Mexico using a physical and empirical model (RUSLE). The importance of the assessment to soil erosion in this area was to find the annual average soil loss rates; Motozintla is an area with high mountains as therefore high topographies becoming an area risky for landslides. However, the use of RUSLE model was a bit difficult to adapt to this area, because Motozintla de Mendoza's vicinities do not have historical databases for supporting this kind of assessments. Despite that, RUSLE model was able to analyze the soil loss per each community, although all the data applied was based on annual averages, the results are taken into account to be the best case.

As results showed in each community Poblado Cambil showed bigger amount of soil erosion rates in most of its plots having a biggest annual soil loss average of 1,700 ton ha ${ }^{-}$ ${ }^{1} \mathrm{yr}^{-1}$, in the plot number 25 while Barrio Plan Grande is the only community with smaller rates in all its plots, however it also shows the smallest annual soil los average of 100 ton $\mathrm{ha}^{-1} \mathrm{yr}^{-1}$ in the plot number 36 , and the biggest annual soil loss average was found in Barrio La Union with a value of 2,050 ton $\mathrm{ha}^{-1} \mathrm{yr}^{-1}$.

Though there has not been other reported studies using data from these communities to model a soil erosion pattern hence not having other results or models to compare this result with, however the use of the RUSLE model has been found to compare well with results obtained using other models(Wang 2001) The second important purpose of this study was to assess the knowledge, attitudes and practices of the community members. 
This assessment was made by conducting a survey in the study area with the goal of understanding the relationship among the soil erosion to the knowledge, attitudes and human practices to control the problem.

There are important lessons learned from these six communities. One of them is that people are concerned about the landslides that occur after period of heavy rain. When it rains a lot, the people say that the lands get moisture making the land easy to collapse, and do not know what to do if more hurricanes occur. At the same time, know that reforestation practices could reduce the soil loss, but many have big families and they do not have more land for reforestation.

Another important lesson learned was that most of the people know that the soil erosion given by landslides are presented in land use with human settlements, and despite to that, they continue clearing the forest by cutting the trees for more houses construction. So, for some of the people to care their lands is very important because from these lands they get their food. On another hand, some people only take advantages of the forest for make money without the awareness of the consequences to the high forest extraction. 


\section{Chapter VIII. RECOMMENDATIONS}

Some recommendations for future studies in the communities studied in the vicinity of Motozintla de Mendoza, Chiapas using RUSLE model in order to assess the soil loss rates are:

- In order to have more accuracy on the results, is recommended to evaluate each factor monthly, however $R$ factor is needed to applied as the model specification require (every $30 \mathrm{~min}$ intensity measurement).

- For $C$ factor is recommended to get the data needed from field and for different time intervals. Some sub-factors used in $C$ factor such as $P L U, C C$ and $S M$ may not be appropriate because they were assumed the best cases.

- As $S M$, soil moisture is not the same through the year, it is better to evaluate it monthly. As this study was evaluated with annual averages.

Recommendations to the communities according the results obtained:

- It is advised to promote the awareness implying first of all environmental education that will help to highlight the areas with environmental problems making sure that the people will have better understanding of the soil erosion, causes and consequences.

- As a result of environmental education the people can promote conservation practices in the specific areas already analyzed in this study.

- Also the results of these study can help to the communities for decision-making for forest restoration, as was explained before, they have small lands for reforestation, at least the continuously reforestation in the Astilleros (common land) could help to keep the land strong. 
- Another recommendation for people with small lands only for crops, they could make reforestation at the corner of their lands or put borders with trees, at the same time those trees can help as barriers for high winds affecting crops or reducing the wind erosion.

- In reforestation conditions, it has to be planted different heights of vegetation (high, medium and lower), different heights of vegetation will reduce the intensity of the rainfall as a result will reduce the soil erosion rate. 


\section{Chapter IX. REFERENCES}

America SSo. 2012. Glossary of Soil Science Terms. Soil Science Society of America

Angima S, Stott D, O'Neill M, Ong C, Weesies G. 2003. Soil erosion prediction using RUSLE for central Kenyan highland conditions. Agriculture, Ecosystems \& Environment 97(1-3):295-308.

Blau J, Moncada A. 2006. Ejidos: A Utopian Project. Public sociologies reader:253.

Brooks KN, Ffolliott PF, Gregersen HM, DeBano LF. 2003. Hydrology and the management of watesheds. Iowa State: Blackwell professional.

Bueno J, Alvarez F, Santiago-Fragoso S, (eds.). 2007. Biodiversidad del Estado de Tabasco. Instituto de Biologia, UNAM y CONABIO, Mexico.

Carfantan JC. 1977. La cobijadura de Motozintla-paleoarco volcánico en Chiapas. Revista mexicana de ciencias geológicas 1(2):133-137.

Castro G. 2009. Explotación minera en Chiapas. Boletín del frente de trabajadores de la energia de México 9(234):4.

Cayuela L, Benayas JMR, Echeverría C. 2006. Clearance and fragmentation of tropical montane forests in the Highlands of Chiapas, Mexico (1975-2000). Forest Ecology and Management 226(1):208-218.

Colegio de Postgraduados C. 2002. Evaluacion de la degradacion del suelo causada por el hombre en la Republica Mexicana escala 1:250,000 Memoria Nacional 20012002. SEMARNAT -Colegio de Postgraduados, Montecillo, Mexico.

FAO. 1995. Land and water integration and river basin management. FAO Corporate document repository. 
Fernandez C, Wu J, McCool D, Stöckle C. 2003. Estimating water erosion and sediment yield with GIS, RUSLE, and SEDD. Journal of soil and Water Conservation 58(3):128-136.

Flamenco-Sandoval A, Martínez Ramos M, Masera OR. 2007. Assessing implications of land-use and land-cover change dynamics for conservation of a highly diverse tropical rain forest. Biological conservation 138(1-2):131-145.

Foster GR. 2005. Science Documentation, Revised Universal Soil Loss Equation Version 2. In: National Sedimentation Laboratory U-ARS, editor. Oxford, Mississippi.

Fournier F. 1960. Climate and Erosion: The Relationship Between Soil Erosion by Water and Atmospheric Precipitations. Presses universitaires de France.

Fu G, Chen S, McCool DK. 2006. Modeling the impacts of no-till practice on soil erosion and sediment yield with RUSLE, SEDD, and ArcView GIS. Soil and tillage research 85(1):38-49.

García-Barrios L, Galván-Miyoshi YM, Valdivieso-Pérez IA, Masera OR, Bocco G, Vandermeer J. 2009. Neotropical forest conservation, agricultural intensification, and rural out-migration: the Mexican experience. Bioscience 59(10):863-873.

Garcia AG. 2011. The transboundary river basin of grijalva; The dance of politics-policy and instutional operative mapping in Mexico and Guatemala. Aqua-LAC 3(2).

Gitas IZ, Douros K, Minakou C, Silleos GN, Karydas CG. 2009. Multi-temporal soil erosion risk assessment in N. Chalkidiki using a modified usle raster model. EARSeL eProceedings 8(1):40-52.

Gordillo GCÁ. 2009. Las percepciones del riesgo. El caso del huracán Stan en Motozintla, Chiapas. Sociedad y desigualdad en Chiapas:24. 
Gestión integrada de crecientes caso de estudio México: río Grijalva (online) [Internet]. 2006. Ginebra, Suiza. [updated cited. Available from: http://www.apfm.info/pdf/case_studies/cs_mexico.pdf

Censo de población y vivienda de Motozintla de Mendoza y Mazapa de Madero, Chiapas. [Internet]. 2010. [updated cited. Available from: http://www.inegi.org.mx/sistemas/mexicocifras/default.aspx?e $=07$ http://www.inegi.org.mx/sistemas/mexicocifras/default.aspx?e=07

Jain SK, Tyagi J, Singh V. 2010. Simulation of Runoff and Sediment Yield for a Himalayan Watershed Using SWAT Model.

Jong BHJ, Ramirez-Marcial N, Ochoa-Gaona S, Mendoza-Vega J, Gonzalez-Espinosa M, March-Mifsut I, Cairns M, Haggerty P. 1999. Land-use change and carbon flux between 1970s and 1990s in central highlands of Chiapas, Mexico. Environmental Management 23(3).

Kouli M, Soupios P, Vallianatos F. 2009. Soil erosion prediction using the revised universal soil loss equation (RUSLE) in a GIS framework, Chania, Northwestern Crete, Greece. Environmental Geology 57(3):483-497.

Lal R. 1995. Global soil erosion by water and carbon dynamics. Soils and global change:131-142.

Launiala A. 2009. How much can a KAP survey tell us about people's knowledge, attitudes and practices? Some observations from medical anthropology research on malaria in pregnancy in Malawi. Anthropology Matters 11(1).

Lopez-Vicente M. 2007. Erosion y restribucion del suelo en agroecosistemans mediterraneros: Modelizacion predictiva mediante SIGm y validacion con $137 \mathrm{Cs}$ (Cuenca de Estaña, Pierineo Central) [Tesis Doctoral]. [Estacion Experimental de Aula Dei, Zaragoza]: Facultad de Ciencias-Universidad de Zaragoza. p. 212. 
Maeda EE, Pellikka PKE, Siljander M, Clark BJF. 2010. Potential impacts of agricultural expansion and climate change on soil erosion in the Eastern Arc Mountains of Kenya. Geomorphology 123(3-4):279-289.

McCool D, Foster G, Weesies G. 1997. Slope-length and steepness factors (LS). Predicting Soil Erosion by Water: A Guide to Conservation Planning with the Revised Universal Soil Loss Equation (RUSLE). USDA Agriculture Handbook(703).

Pieri L, Bittelli M, Wu JQ, Dun S, Flanagan DC, Pisa PR, Ventura F, Salvatorelli F. 2007. Using the Water Erosion Prediction Project (WEPP) model to simulate field-observed runoff and erosion in the Apennines mountain range, Italy. Journal of hydrology 336(1):84-97.

Ramírez-Marcial N, González-Espinosa M, Williams-Linera G. 2001. Anthropogenic disturbance and tree diversity in montane rain forests in Chiapas, Mexico. Forest Ecology and Management 154(1-2):311-326.

Renard KG, Foster GR, Weesies GA, Porter JP. 1991. RUSLE: Revised universal soil loss equation. Journal of soil and Water Conservation 46(1):30-33.

Renard KG, Freimund JR. 1994. Using monthly precipitation data to estimate the Rfactor in the revised USLE. Journal of hydrology 157(1-4):287-306.

Renard KG, Foster GR, Weesies GA, McCool D, Yoder D. 1997. Predicting soil erosion by water: a guide to conservation planning with the revised universal soil loss equation (RUSLE). Agriculture Handbook (Washington)(703).

Renschler CS. 2003. Designing geo-spatial interfaces to scale process models: the GeoWEPP approach. Hydrological Processes 17(5):1005-1017. 
Rodríguez S N, Ruiz J E, Valenzuela P A, Belmar N C. 2000. Efecto del sistema de laboreo en las pérdidas de suelo por erosión en la rotación trigo-avena y praderas en la precordillera andina de la región centro sur. Agricultura Técnica 60(3):259269.

Romkens M. 1985. Soil Erodibility Factor: A Perspective. Soil Erosion and Conservation. Soil Conservation Society of America, Ankeny, Iowa. 1985. p 445461, 1 fig, 5 tab, 31 ref.

Roose E. 1996. Land husbandry: components and strategy. Food Agriculture Organization of the United Nations. Soil Resources, Management, Conservation Service

Sánchez-Núñez JM, Macías JL, Zamorano-Orozco JJ, Saucedo R, Torres JR, Novelo D. 2012. Mass movement processes at the Motozintla Basin, Chiapas, Southern Mexico. GEOFÍSICA INTERNACIONAL 51(2):169-186.

Santacruz-DeLeon G. 2011. Estimate of water erosion and its relationship to land use in the cahoacan river basin, Chiapas, Mexico. International Hydrological Programme (IHP) of the United Nations Educational, Scientific and Cultural Organization (UNESCO) 3(1):45.

Scharff M. 2005. Comparison of RUSLE and RUSLE2 to determine water quality treatment of vegetated strips. Storm water program.

SEMARNAT. 2002. NOM-021-RECNAT-2000. Parte 2: Especificaciones de fertilidad, salinidad y clasificaciones de suelos. Estudios, muestreo y analisis. Mexico, Diario Oficial de la Federacion (D.O.F). 
Suarez-Diaz J. 2006. Analisis de los problemas de erpsion de deslaves; Carretera HuixtlaMotozintla, Chiapas. Instituto de erosion y deslizamientos, Bucaramanga, Colombia.

Tiwari A, Risse L, Nearing M. 2000. Evaluation of WEPP and its comparison with USLE and RUSLE.

Walker KEaR. 2008. Knowledge, Attitudes and Practice (KAP) Survey Summary Report for the Duluth Lakeside Stormwater Reduction Project (LSRP). Water Resources Center.

Wang W-f. 2001. Investigation of land erosion model of Houzhaihe catchment in Puding, Guizhou and its application. Guizhou Geology.

WHO. Advocacy, communication and social mobilization for TB control: a guide to developing knowledge, attitude and practice surveys. [Internet]. 2008 [cited 2012 July 15]. Available from: http://whqlibdoc.who.int/publications/2008/9789241596176_eng.pdf

Williams J. 1990. The erosion-productivity impact calculator (EPIC) model: A case history. Philosophical Transactions of the Royal Society of London. Series B: Biological Sciences 329(1255):421-428.

Wischmeier W. H. and Smith DD. 1978. Predicting rainfall erosion losses a guide to conservation planing. Agricultural Handbook No. 537.

Yue-qing X, Jian P, Xiao-mei S. 2008. Assessment of soil erosion using RUSLE and GIS: a case study of the Maotiao River watershed, Guizhou Province, China. Environmental Geology 56(8):1643-1652. 
Zhang X, Srinivasan R, Debele B, Hao F. 2008. Runoff Simulation of the Headwaters of the Yellow River Using The SWAT Model With Three Snowmelt Algorithms1. JAWRA Journal of the American Water Resources Association 44(1):48-61. 


\section{Chapter X. APPENDIX}

González-Morales 79 


\title{
A. Social survey support
}

\section{Permission letter}

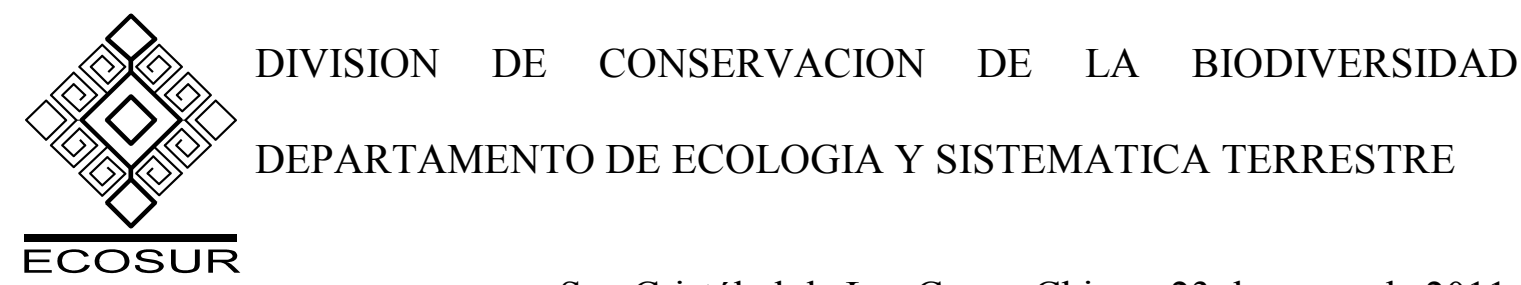

San Cristóbal de Las Casas, Chis., a 23 de enero de 2011

Asunto: Solicitud de permiso para realizar entrevistas

\section{Agente Municipal de}

\section{Municipio de Motozintla de Mendoza, Chiapas}

\section{P R E S E N T E}

Por este conducto, hago de su conocimiento que la C. Selene Berenice González Morales, estudiante de maestría en ingeniería ambiental, está colaborando con El Colegio de la Frontera Sur (ECOSUR) en el desarrollo del proyecto de manejo integral de cuencas. Debido a que parte del trabajo de la Srita. Selene González consiste en realizar un análisis de la pérdida de suelos en diferentes comunidades, es necesario tener acceso a la población para llevar a cabo algunas entrevistas a personas mayores de 18 años dentro de la comunidad. Este trabajo de ninguna manera implica algún daño o destrucción de los recursos locales o afectación alguna del orden público, pues al contrario, se espera que los resultados de este estudio podrán ser de utilidad para la misma comunidad. Para ello, nos comprometemos a entregar al final del estudio toda la información que se obtenga de este estudio.

Por lo anterior, mucho agradeceré las facilidades y ayuda que le pueda proporcionar a la C. Selene Berenice González para que pueda llevar a buen término sus actividades planeadas.

Por la atención que se sirvan prestar a la presente, quedo de usted,

Atentamente

\author{
Dr. Neptalí Ramírez-Marcial \\ Investigador Titular
}

C.c.p. Dr. Mario González-Espionosa. Responsable del proyecto "Gestión y estrategias de manejo sustentable para el desarrollo regional en la cuenca hidrográfica transfronteriza Grijalva". ECOSUR. Presente 


\section{Questionnaire for KAP surveys}

\section{ENGLISH VERSION}

Knowledge, attitudes and practices survey (KAP) on soil erosion.

Community:

Date:

Time:

Home number:

Name of Interviewer:

1.-What is your name?

2.-How old are you? Years

3.-Sex: F/M

4.-What level of studies do you have?

a) Elementary school___ (Year) b) Secondary school__ (Year) c) High school____(Year) d)Other (specify) (Year)

5.-How long have you been living in this community? (Years)

6.-Where do you work?

a) In your own land (inside of your lands b) Village (outside the house)

c) Outside the Village d) Other (specify)

7.-Do you receive some economics incomes? No/ Yes

(If it is yes, ask the following)

8.-What kind of payment do you receive?
a) Wage
b) Support of some government program
(Specify)

9.-How much do you earn each month?
a) Equal or less than 1000
b) 1500
c) 2000
d) Equal or more than 2500 


\section{Knowledge:}

1.-Have you heard about the problems of soil erosion (soil loss caused by water or wind)? $\mathrm{No} / \mathrm{Yes}$

2.-Do you know what soil erosion is?

3.-Do you know what the most eroded area of the community is?

4.-Do you know the extent of eroded area (hectares)?

5.-Do you know since when it has been eroded?

6.-Do you know what caused or what were the factors of soil erosion in these areas?

7.-What kind of land use is into those eroded areas?

8.-How long those areas have been used (years)?
a)Less than 5 Years
b) 5 Years
c) 10 Years
d) 15 Years
e)over 15 years

9.-Do you know which are the consequences of having areas with ease of erosion?

10.-Where they got the knowledge's from?
A) Family
b) School
c) Government programs
d) Church
e) Other (specify) 
Attitudes:

Having the knowledge of areas subject to soil erosion:

1.-Do you think there are solutions to the problem? No / Yes

2.-How would you help to reduce these areas?

3.-If in your locality a landslide occurs, what do you do in those times?

4.-Who do you think should solve the problem of erosion?

\section{Practices:}

1. - What are the practices to reduce soil erosion in your community? 


\section{SPANISH VERSION}

Encuestas de Conocimientos, Actitudes y Practicas (CAP) sobre la erosión de suelos.

Comunidad:

Fecha:

Hora:

Numero de casa:

Nombre del entrevistador (a):

1.-¿Cuál es su nombre?

2.-¿Cuántos años tiene? años

3.-Sexo: F/M

4.- ¿Qué grado de estudio tiene?

Primaria (Año)Secundaria (Año)Preparatoria (Año)Otro (especifique) (Año)

5.- ¿Cuánto tiempo tiene viviendo en esta comunidad? (años)

6.- ¿Dónde trabaja usted?

a) En su propio terreno b) Pueblo (Fuera de casa) ,c) Fuera del pueblo , d) Especifique

7.- ¿Recibe ingresos económicos? No/Si

(Si la respuesta es si, preguntar lo siguiente)

8.- ¿Que tipo de pago recibe?

a) Salario

b) Apoyo de algún programa de gobierno (especifique)

9.- ¿Cuánto gana mensualmente?

a) Igual o menos de 1000

b) 1500

c) 2000 d) Igual o más de 2500 


\section{Conocimientos:}

1.- ¿Ha escuchado acerca del problema de la erosión de suelos, (perdida de suelo por causa de agua o viento)? No / Si

2.- ¿Sabe usted que es la erosión de suelos?

3.- ¿Sabe usted, cual es el área mas erosionada de la comunidad?

4.- ¿Sabe usted, cual es la extensión del área erosionada (hectáreas)?

5.- ¿Sabe usted desde cuando se ha ido erosionando? -

6.- ¿Sabe usted, qué ocasiono o cuales fueron los factores de la erosión del suelo de esas áreas?

7.- ¿Sabe usted, que tipo de uso de suelo esta dentro de las áreas erosionadas?

8.- ¿Sabe usted, hace cuando tiempo se han estado usando esas áreas (años)?
a) Menos de 5 años
b) 5 años
c) 10 años
d) 15 años
e) Más de 15 años

9.- ¿Sabe usted, cuáles son las consecuencias de tener áreas con facilidad de erosión?

10.- ¿De donde obtuvo usted estos conocimientos?
a) Familia
b) Escuela
c) Programas de gobierno
d) Iglesia
e) Otros (Especifique) 


\section{Actitudes:}

Teniendo los conocimientos acerca de las áreas sujetas a la erosión de suelos:

1.- ¿Piensa usted que hay soluciones al problema? No / Si

2.- ¿Como ayudaría a reducir esas áreas?

3.- ¿Si en tu comunidad ocurre un deslave, que hace usted en esos momentos?

4.- ¿Quien cree usted que debería de resolver los problemas de erosión?

\section{Prácticas:}

¿Cuáles son las prácticas para reducir la erosión de suelos en su comunidad? 


\section{Consent statement}

\section{ENGLISH VERSION}

\section{Orally Given Informed Consent Statement}

"I am a student of the Master of Science in Environmental Engineering from Michigan Technological University, I am conducting an assessment of soil vulnerability to erosion in (the community of ...) and also in other communities in Motozintla de Mendoza , Chiapas. The information collected will be presented in an academic report. It is expected that the results of this study will be useful to the community. I would like to ask you specific questions about knowledge, attitudes and practices regarding soil loss. You can make me questions or offer other information you consider important, even if information not requested. The survey will last approximately 40 minutes.

You are not required to speak with me or answer all questions. If you agree to answer questions now, and later during the survey decide you do not want answer, you can tell me as well. In the same way, if you do not want to answer a question, you can tell me and move to the next. Nothing bad can happen, either you or me, if you decide not to participate in the survey. " 


\section{SPANISH VERSION}

\section{Declaración Verbal de Consentimiento Informado}

“Soy estudiante de la Maestría en Ciencias en Ingeniería Ambiental de la Universidad Tecnológica de Michigan; estoy realizando una evaluación de la vulnerabilidad del suelo a la erosión (la comunidad de ...) y también en otras comunidades Motozintla de Mendoza, Chiapas. La información recogida se presentará en un reporte académico. Se espera que los resultados de este estudio puedan ser de utilidad para la misma comunidad. Me gustaría hacerle(s) preguntas especificas sobre conocimientos, actitudes y practicas referente a la perdida de suelos. Usted también me puede hacer preguntas u ofrecer otras informaciones que usted considere importante, aunque sea información que no solicito. La encuesta tendrá una duración de aproximadamente $\underline{40}$ minutos.

No es obligación que usted hable conmigo o que conteste todas las preguntas. Si usted está de acuerdo en contestar las preguntas ahora, y después o durante la encuesta decide que ya no quiere contestar, puede decírmelo también. De igual manera. Si usted no quiere contestar una pregunta, puede decirlo, y pasaremos a la próxima. Nada malo puede pasarnos, ni a usted, ni a mí, si usted decide que no quiere participar en la encuesta.” 
B. Supporting calculations (CD)

\title{
1. RUSLE Calculations factors folder
}

\author{
1.1 Factor $R$
}

1.2 Factor $K$

1.3 Factors $L$ and $S$

1.4 Factor $C$

1.5 Annual average of soil loss rates $A$

C. Social survey folder (CD)

1. Survey general questions and responses per community 